\title{
Modelling planktic foraminifer growth and distribution using an ecophysiological multi-species approach
}

\author{
F. Lombard ${ }^{1,3^{*}}$, L. Labeyrie ${ }^{1}$, E. Michel ${ }^{1}$, L. Bopp ${ }^{1}$, E. Cortijo ${ }^{1}$, S. Retailleau ${ }^{2}$, H. Howa ${ }^{2}$, and F. Jorissen ${ }^{2}$ \\ ${ }^{1}$ LSCE/IPSL, laboratoire CEA/CNRS/UVSQ, LSCE-Vallée, Bât. 12, avenue de la Terrasse, 91198 Gif-sur-Yvette \\ CEDEX, France \\ ${ }^{2}$ Laboratory of Recent and Fossil Bio-Indicators (BIAF), Angers University, UPRES EA 2644, 2 Boulevard Lavoisier, 49045 \\ Angers Cedex, France \\ ${ }^{3}$ Technical University of Denmark, National Institute for Aquatic Resources, Oceanography Section, Kavalergården 6, 2920 \\ Charlottenlund, Denmark \\ *now at: Université de la Méditerranée, CNRS, Laboratoire d'Océanographie Physique et Biogéochimique, LOPB - UMR \\ 6535 Campus de Luminy, Case 901, 13288 MARSEILLE Cedex 9, France
}

Received: 6 October 2010 - Published in Biogeosciences Discuss.: 4 January 2011

Revised: 11 March 2011 - Accepted: 23 March 2011 - Published: 8 April 2011

\begin{abstract}
We present an eco-physiological model reproducing the growth of eight foraminifer species (Neogloboquadrina pachyderma, Neogloboquadrina incompta, Neogloboquadrina dutertrei, Globigerina bulloides, Globigerinoides ruber, Globigerinoides sacculifer, Globigerinella siphonifera and Orbulina universa). By using the main physiological rates of foraminifers (nutrition, respiration, symbiotic photosynthesis), this model estimates their growth as a function of temperature, light availability, and food concentration. Model parameters are directly derived or calibrated from experimental observations and only the influence of food concentration (estimated via Chlorophyll- $a$ concentration) was calibrated against field observations. Growth rates estimated from the model show positive correlation with observed abundance from plankton net data suggesting close coupling between individual growth and population abundance. This observation was used to directly estimate potential abundance from the model-derived growth. Using satellite data, the model simulate the dominant foraminifer species with a $70.5 \%$ efficiency when compared to a data set of 576 field observations worldwide. Using outputs of a biogeochemical model of the global ocean (PISCES) instead of satellite images as forcing variables gives also good results, but with lower efficiency (58.9\%). Compared to core tops observations, the model also correctly reproduces the relative worldwide abundance and the diversity of the eight species when using either satellite data either PISCES
\end{abstract}

Correspondence to: F. Lombard (lombardfa@gmail.com) results. This model allows prediction of the season and water depth at which each species has its maximum abundance potential. This offers promising perspectives for both an improved quantification of paleoceanographic reconstructions and for a better understanding of the foraminiferal role in the marine carbon cycle.

\section{Introduction}

Planktic foraminifers occur at low abundance in marine waters compared to both protozoans and zooplankton (e.g., Albaina and Irigoien, 2007). After gametogenesis or death of the organism, their calcite tests sink through the water column with high sinking rates (Takahashi and Bé, 1984), and accumulate at the sea floor, contributing significantly to the marine carbonate flux (Schiebel, 2002). Fossil shells are commonly used in paleoceanography to reconstruct past climatic conditions and variability through the use of different proxies such as species assemblage composition or shell chemistry (e.g. Waelbroeck et al., 2009). However, interpretation of these proxies requires a precise knowledge of the environmental conditions (season and/or depth) of shell calcification. Unfortunately, environmental and biological studies cover only a small geographic range of the world ocean (e.g., Field, 2004; Schiebel et al., 2001) and laboratory observations are scarce (Bijma et al., 1990). The observed composition of the analysed shells is explained on the basis of a statistical comparison between modern surface hydrology and shells extracted from sediment core tops (Imbrie and Kipp, 1971; Kucera et al., 2005) without consideration

Published by Copernicus Publications on behalf of the European Geosciences Union. 
of biological mechanisms such as seasonality or potential deeper habitat in the water column (e.g. Cleroux et al., 2007; King and Howard, 2005). Planktic foraminiferal seasonality and depth preferences in the ocean waters, as well as growth under laboratory conditions, are strongly linked to environmental conditions, mainly temperature, light (for species with symbionts) and food availability (Bijma et al., 1990; Kuroyanagi and Kawahata, 2004; Lombard et al., 2009b; Schiebel et al., 2001; Spero and Parker, 1985). Thus the physiological adaptation of the different species may explain, in part, the environmental range under which each species exhibits an optimal growth (Lombard et al., 2009b), as well as their seasonal and vertical distribution. The environmental control of foraminifer physiology may be described by a model, which takes into account the sensitivity of each physiological process with respect to various environmental factors. In the past years, several models of foraminifer abundance have been developed based on environmental parameters (Fraile et al., 2008; Žarić et al., 2006). Recently, Fraile et al. (2008) presented a model simulating the abundance of six different species, using parameters which have been calibrated empirically by field measurements.

In this study, we used a physiological formulation to model the growth of foraminifers for the most abundant planktic foraminifer species living in the ocean surface and subsurface waters. The presented FORAMCLIM growth model is based on the assumption that the presence or absence of species is linked to their ability to grow, depending on the environmental conditions. The model reproduces the physiological rates involved in the growth of planktic foraminifers, based on metabolic processes observed under controlled laboratory experiments. The calibration has been made following two steps: First we attempt to reproduce observed growth under laboratory conditions as a function of temperature and light intensity. Second, we attempt to reproduce observed abundance in field conditions, for which hydrological parameters have been measured. The model has been validated against both global plankton tows and sediment core tops observations independent of the dataset used for the calibration. The model reproduces the relative abundances of the different species on a global scale, and the season and depth of the maximal potential abundance of each species is estimated.

\section{General growth model conception and calibration}

In the first part, we will present the model, which describes the growth of an individual foraminifer. Construction of the growth model is based on observed processes during laboratory experiments or observations and is kept as simple as possible by taking in consideration only well calibrated processes. Eight planktic foraminiferal species are considered: Neogloboquadrina pachyderma (sinistral), Neogloboquadrina incompta (N. pachyderma dextral cf. Darling et al., 2006), Neogloboquadrina dutertrei, Globigerina bul- loides, Globigerinoides ruber, Globigerinoides sacculifer, Globigerinella siphonifera and Orbulina universa. The species are among the most abundant species in the marine ecosystem and are most used in both laboratory experiments and paleoclimate reconstruction.

\subsection{Individual foraminifer growth}

The model simulates the growth of the foraminiferal organic component (cytoplasm), but does not yet consider test growth. The growth model simulates foraminifer organic weight increase $\left(\Delta W, \mu \mathrm{gC} \mathrm{d}^{-1}\right)$ as a function of the main physiological processes: nutrition $\left(N, \mu \mathrm{gCd}^{-1}\right)$, respiration $\left(R, \mu \mathrm{gC}^{-1}\right)$ and, for species with symbionts, photosynthesis $\left(P, \mu \mathrm{gC}^{-1}\right)$. Those processes depend on variables like temperature $\left(T,{ }^{\circ} \mathrm{K}\right)$, light availability $(L, \mu$ mole photon $\left.\mathrm{m}^{-2} \mathrm{~s}^{-1}\right)$ and food concentration $\left(F, \mu \mathrm{gCl} 1^{-1}\right)$. Variables, parameters and units are described in Table 1.

\subsubsection{Nutrition}

Foraminifers are poikilotherms protozoans and thus do not regulate their temperature. Poikilotherms feeding processes such as the speed of prey capture and digestion generally depend on water temperature (Kooijman, 2000). Moreover, at extreme low or high temperatures, a sharp decrease in the growth rates is observed in foraminifers (Bijma et al., 1990; Lombard et al., 2009b). Moreover, Bé et al. (1981) have shown that the growth rate of $G$. sacculifer is a saturating function of feeding frequency. In the model, we use a Michaelis-Menten kinetics to reproduce this saturation of feeding as a function of food availability, and the temperature dependence follows a mechanistic formulation derived from Arrhenius rate kinetics. The nutrition rate $N$ is expressed as a function of temperature $T$ (in Kelvin) and food concentration $(F)$ :

$N(T, F)=N_{\max }\left(T_{1}\right) \frac{\exp \left(\frac{T_{A}}{T_{1}}-\frac{T_{A}}{T}\right)}{1+\exp \left(\frac{T_{\mathrm{AL}}}{T}-\frac{T_{\mathrm{AL}}}{T_{L}}\right)+\exp \left(\frac{T_{\mathrm{AH}}}{T_{H}}-\frac{T_{\mathrm{AH}}}{T}\right)} \frac{F}{F+k_{n}}(1)$

where $k_{\mathrm{n}}\left(\mu \mathrm{g} \mathrm{C} 1^{-1}\right)$ is the half saturation constant for the Michaelis-Menten relationships; $N_{\max }\left(T_{1}\right)\left(\mu \mathrm{gC} \mathrm{d}^{-1}\right)$ is the maximum nutrition rate for an arbitrary chosen temperature $T_{1}\left(20^{\circ} \mathrm{C}\right.$ or $293^{\circ} \mathrm{K}$ in this study); $T_{\mathrm{A}}$ is the Arrhenius temperature for nutrition rate; $T_{\mathrm{L}}$ and $T_{\mathrm{H}}$ are the lower and upper boundaries of the enzymes tolerance range and $T_{\mathrm{AL}}$ and $T_{\mathrm{AH}}$ are the Arrhenius temperatures for the rate of decrease at both boundaries. All $T$ are taken to be positive and generally $T_{\mathrm{AH}}>T_{\mathrm{AL}}>T_{\mathrm{A}}$. By using this relationship the model reproduces simultaneously the nutrition saturation at high food concentration, the nutrition increase with temperature, and a sharp decrease of growth observed for extreme temperatures, which results in an asymmetrical bell shaped curve (Lombard et al., 2009b). 
Table 1. Symbols, description and units of the different variables and parameter used in the model.

\begin{tabular}{|c|c|c|}
\hline Symbol & Description & Unit \\
\hline \multicolumn{3}{|c|}{ Forcing variables } \\
\hline$T$ & Temperature & ${ }^{\circ} \mathrm{K}$ \\
\hline$L$ & Light availability & $\mu$ mole photon $\mathrm{m}^{-2} \mathrm{~s}^{-1}$ \\
\hline$F$ & Food concentration & $\mu \mathrm{g} \mathrm{Cl}^{-1}$ \\
\hline $\mathrm{dl}$ & Day length & $d^{-1}$ \\
\hline \multicolumn{3}{|c|}{ State variables } \\
\hline$W_{\mathrm{f}}$ & Final foraminifer organic weight & $\mu \mathrm{g} \mathrm{C}$ ind $^{-1}$ \\
\hline$\Delta W$ & Organic weight increase & $\mu \mathrm{g} \mathrm{Cd}^{-1}$ \\
\hline$\mu$ & grow rate & $d^{-1}$ \\
\hline \multicolumn{3}{|l|}{ Fluxes } \\
\hline$N$ & Nutrition & $\mu \mathrm{g} \mathrm{C} \mathrm{d}^{-1}$ \\
\hline$R$ & Respiration & $\mu \mathrm{g} \mathrm{Cd}^{-1}$ \\
\hline$P$ & Symbiont photosynthesis & $\mu \mathrm{g} \mathrm{Cd}^{-1}$ \\
\hline \multicolumn{3}{|l|}{ Parameters } \\
\hline$W_{\mathrm{i}}$ & Initial foraminifer organic weight (size $250 \mu \mathrm{m})$ & $\mu \mathrm{g} \mathrm{C}$ ind $^{-1}$ \\
\hline \multicolumn{3}{|l|}{ Nutrition } \\
\hline$N_{\max }\left(T_{1}\right)$ & Maximum nutrition rate at $T_{1}$ & $\mu \mathrm{g} \mathrm{Cd}^{-1}$ \\
\hline$k_{\mathrm{n}}$ & Half saturation constant for nutrition & $\mu \mathrm{g} \mathrm{C}^{-1}$ \\
\hline$T_{\mathrm{AH}}$ & Arrhenius temperatures for the rate of decrease at upper boundary & ${ }^{\circ} \mathrm{K}$ \\
\hline$T_{\mathrm{H}}$ & Upper boundary of the enzymes tolerance range & ${ }^{\circ} \mathrm{K}$ \\
\hline$T_{\mathrm{AL}}$ & Arrhenius temperatures for the rate of decrease at lower boundary & ${ }^{\circ} \mathrm{K}$ \\
\hline$T_{\mathrm{L}}$ & Lower boundary of the enzymes tolerance range & ${ }^{\circ} \mathrm{K}$ \\
\hline$T_{\mathrm{A}}$ & Arrhenius temperature for nutrition rate & ${ }^{\circ} \mathrm{K}$ \\
\hline \multicolumn{3}{|c|}{ Respiration } \\
\hline & Arrhenius temperature for respiration rate & ${ }^{\circ} \mathrm{K}$ \\
\hline$R_{\max }\left(T_{1}\right)$ & Respiration rate for a $250 \mu \mathrm{m}$ sized foraminiferan at $T_{1}$ & $\mu \mathrm{g} \mathrm{Cd}^{-1}$ \\
\hline \multicolumn{3}{|c|}{ Photosynthesis } \\
\hline$P_{\max }\left(T_{1}\right)$ & Maximum photosynthesis rate per symbiont at $T_{1}$ & $\mu \mathrm{g} \mathrm{Cd}^{-1}$ \\
\hline$k_{\mathrm{p}}$ & Half saturation constant for photosynthesis & $\mu$ mole photon $\mathrm{m}^{-2} \mathrm{~s}^{-1}$ \\
\hline$T_{\mathrm{Ap}}$ & Arrhenius temperature for photosynthesis rate & ${ }^{\circ} \mathrm{K}$ \\
\hline$s_{\mathrm{nb}}$ & Symbiont number for a $250 \mu \mathrm{m}$ sized foraminiferan & nb ind ${ }^{-1}$ \\
\hline$\% \mathrm{p}$ & Photosynthesis fraction used for the foraminifera-symbiont complex growth & - \\
\hline
\end{tabular}

\subsubsection{Photosynthesis and respiration}

Photosynthesis is carried out by symbionts and therefore depends on the number of symbionts hosted by the foraminifer. Thus photosynthesis is calculated on a per symbiont basis multiplied by the symbiont number of a $250 \mu \mathrm{m}$ sized foraminifer $\left(s_{\mathrm{nb}}\right)$. Photosynthesis also depends on light availability $\left(L, \mu\right.$ mole photon $\left.\mathrm{m}^{-2} \mathrm{~s}^{-1}\right)$ and reaches saturation for high light intensities (Jørgensen et al., 1985; Köhler-Rink and Kühl 2005; Spero and Parker, 1985). The model reproduces this process by using a Michaelis-Menten relationship as a function of the light availability. Warming also increases the photosynthesis rate following an Arrhenius kinetics (Lombard et al., 2009a). The combined effect of light intensity and temperature can thus be estimated as:

$P(T, \mathrm{~L})=s_{\mathrm{nb}} P_{\max }\left(T_{1}\right) \exp \left(\frac{T_{\mathrm{Ap}}}{T_{1}}-\frac{T_{\mathrm{Ap}}}{T}\right) \frac{\mathrm{L}}{\mathrm{L}+k_{p}}$

where $k_{\mathrm{p}} \quad\left(\mu\right.$ mole photon $\left.\mathrm{m}^{-2} \mathrm{~s}^{-1}\right)$ is the half saturation constant for the Michaelis-Menten relationships; $P_{\max }\left(T_{1}\right)\left(\mu \mathrm{gC} \mathrm{d}^{-1}\right)$ is the maximum photosynthesis rate per symbiont for the arbitrarily chosen temperature $T_{1}$ and $T_{\mathrm{Ap}}\left({ }^{\circ} \mathrm{K}\right)$ is the Arrhenius temperature for photosynthesis rate. 
Table 2. Parameters values for the different foraminifer species.

\begin{tabular}{|c|c|c|c|c|c|c|c|c|c|}
\hline & O. universa & G. sacculifer & G. siphonifera & G. ruber & N. dutertrei & G. bulloides & N. incompta & N. pachyderma & Units \\
\hline \multicolumn{10}{|l|}{ Nutrition } \\
\hline$N_{\max }\left(T_{1}\right)$ & 0.21 & 0.29 & 0.19 & 0.19 & 0.17 & 0.31 & 0.18 & 0.19 & $\mu \mathrm{g} \mathrm{Cd}^{-1}$ \\
\hline$k_{\mathrm{n}}$ & 1.73 & 1.32 & 1.19 & 0.51 & 1.00 & 6.84 & 3.33 & 4.70 & $\mu \mathrm{g} \mathrm{Cl}^{-1}$ \\
\hline$T_{\mathrm{AH}}$ & 74313 & 102000 & 39284 & 47496 & 32319 & 52575 & 51836 & 23802 & ${ }^{\circ} \mathrm{K}$ \\
\hline$T_{\mathrm{H}}$ & 305 & 305 & 302 & 303 & 304 & 299 & 296 & 281 & ${ }^{\circ} \mathrm{K}$ \\
\hline$T_{\mathrm{AL}}$ & 31002 & 51870 & 270000 & 44807 & 103000 & 202000 & 164000 & 20900 & ${ }^{\circ} \mathrm{K}$ \\
\hline$T_{\mathrm{L}}$ & 287 & 289 & 285 & 291 & 281 & 281 & 277 & 260 & ${ }^{\circ} \mathrm{K}$ \\
\hline$T_{\mathrm{A}}$ & 5598 & 3523 & 10427 & 7852 & 8536 & 9006 & 8347 & 3287 & ${ }^{\circ} \mathrm{K}$ \\
\hline \multicolumn{10}{|c|}{ Respiration } \\
\hline$T_{\mathrm{Ar}}$ & 10293 & 10293 & 10293 & 10293 & 10293 & 10293 & 10293 & 10293 & ${ }^{\circ} \mathrm{K}$ \\
\hline$R_{\max }\left(T_{1}\right)$ & 0.0822 & 0.0822 & 0.0822 & 0.0822 & 0.0822 & 0.0822 & 0.0822 & 0.0822 & $\mu \mathrm{g} \mathrm{C} \mathrm{d}^{-1}$ \\
\hline \multicolumn{10}{|c|}{ Photosynthesis } \\
\hline$P_{\max }\left(T_{1}\right)$ & 0.00054 & 0.00054 & 0.00054 & 0.00054 & - & - & - & - & $\mu \mathrm{gC} \mathrm{d}^{-1}$ \\
\hline$k_{\mathrm{p}}$ & 120 & 120 & 120 & 120 & - & - & - & - & $\mu$ mole photon $\mathrm{m}^{-2} \mathrm{~s}^{-1}$ \\
\hline$T_{\mathrm{Ap}}$ & 9026 & 9026 & 9026 & 9026 & - & - & - & - & ${ }^{\circ} \mathrm{K}$ \\
\hline$s_{\mathrm{nb}}$ & 716 & 1160 & 720 & 1104 & - & - & - & - & $\mathrm{nb}(250 \mu \mathrm{m}) \mathrm{ind}^{-1}$ \\
\hline$\%_{\mathrm{p}}$ & 0.46 & 0.40 & 0.30 & 0.37 & - & - & - & - & fraction \\
\hline \multicolumn{10}{|l|}{ Abundance } \\
\hline$a$ & 0.40 & 1.40 & 0.37 & 8.21 & 0.10 & 0.57 & 0.07 & 1.65 & scaling factor \\
\hline$b$ & 1.63 & 5.89 & 11.20 & 2.79 & 34.99 & 15.85 & 55.36 & 32.13 & scaling factor \\
\hline
\end{tabular}

In a similar way, foraminifer respiration increases with temperature following an Arrhenius kinetics (Lombard et al., 2009a) and respiration can be defined as:

$R(T)=R\left(T_{1}\right) \exp \left(\frac{T_{\mathrm{Ar}}}{T_{1}}-\frac{T_{\mathrm{Ar}}}{T}\right)$

where $R\left(T_{1}\right)\left(\mu \mathrm{gC} \mathrm{d}^{-1}\right)$ is the respiration rate for a $250 \mu \mathrm{m}$ sized foraminifer at the arbitrary chosen temperature $T_{1}$ and $T_{\mathrm{Ar}}\left({ }^{\circ} \mathrm{K}\right)$ is the Arrhenius temperature for respiration rate.

\subsubsection{Foraminifer growth}

To simulate the growth rate, all species are defined with the same initial organic weight $\left(W_{\mathrm{i}} ; 0.73 \mu \mathrm{gC}\right)$ corresponding to a $250 \mu \mathrm{m}$ sized foraminifer (Michaels et al., 1995). This foraminifer size was chosen in order to correspond to most growth and physiological rate observations in laboratory experiments. The final organic weight $W_{\mathrm{f}}$ is then simulated by the model on a daily basis by taking into account the foraminifer ecophysiology (respiration, photosynthesis, and nutrition) for a $W_{\mathrm{i}}$ weight.

In case of symbiont bearing foraminifers, the model simulates growth of the symbiont/foraminifer complex, without differentiation between symbiont and foraminifer growths.

Photosynthesis only takes place during day length (dl, $\left.\mathrm{d}^{-1}\right)$ and we assume that only a fraction $\left(\%_{p}\right)$ of the symbiont photosynthesis potentially contributes to the growth of the foraminifer/symbiont complex (Lombard et al., 2009a). The weight increment $\Delta W$, which serves to calculate $W_{\mathrm{f}}$ is calculated on a daily basis such as:

$\Delta W=N+\%_{p} d l P-R$
The growth rate $\left(\mu, \mathrm{d}^{-1}\right)$ is calculated on a daily basis assuming an exponential growth of foraminifer organic content and using the following formulation:

$\mu=\ln \left(W_{\mathrm{f}} / W_{\mathrm{i}}\right)$

\subsubsection{Data from culture experiments and growth model calibration}

Parameters are listed and described in Table 1, and values taken either from bibliography or from calibration are listed in Table 2. Because temperature have a similar effect among species on respiration and photosynthesis, parameters $R\left(T_{1}\right), T_{\mathrm{Ap}}$ and $T_{\mathrm{Ar}}$ are directly issued from Lombard et al. (2009a) and are assumed to be the same for all species. Symbiont number $\left(s_{\mathrm{nb}}\right)$ for a $250 \mu \mathrm{m}$ size for $O$. univers $a$ and G. siphonifera were estimated in Spero and Parker (1985) and Faber et al. (1988), respectively. As O. universa, G. sacculifer and G. ruber have the same symbiont type (Hemleben et al., 1989), they are assumed to produce photosynthesis in the same way. $s_{\mathrm{nb}}$ for $G$. sacculifer was estimated from Jørgensen et al. (1985) (foraminifer size $<300 \mu \mathrm{m}$ ) with photosynthesis re-evaluated for comparison at $25^{\circ} \mathrm{C}$, and compared to the photosynthesis rate of one individual symbiont observed for $O$. universa at $25^{\circ} \mathrm{C}$ (Spero and Parker, 1985). The same estimation was done for $G$. ruber by using photosynthesis results from Lombard et al. (2009a), and Gastrich and Bartha (1988). $P_{\max }\left(T_{1}\right)$ and $k_{\mathrm{p}}$ were estimated by combining results from Jørgensen et al. (1985), Spero and Parker (1985), and Rink et al. (1998) re-evaluated to the reference temperature of $20^{\circ} \mathrm{C}$, and on a per symbiont basis.

Parameters $N_{\max }\left(T_{1}\right), T_{\mathrm{A}}, T_{\mathrm{L}}, T_{\mathrm{H}}, T_{\mathrm{AL}}, T_{\mathrm{AH}}$, and $\%_{p}$ were calibrated by using growth observations from Lombard 

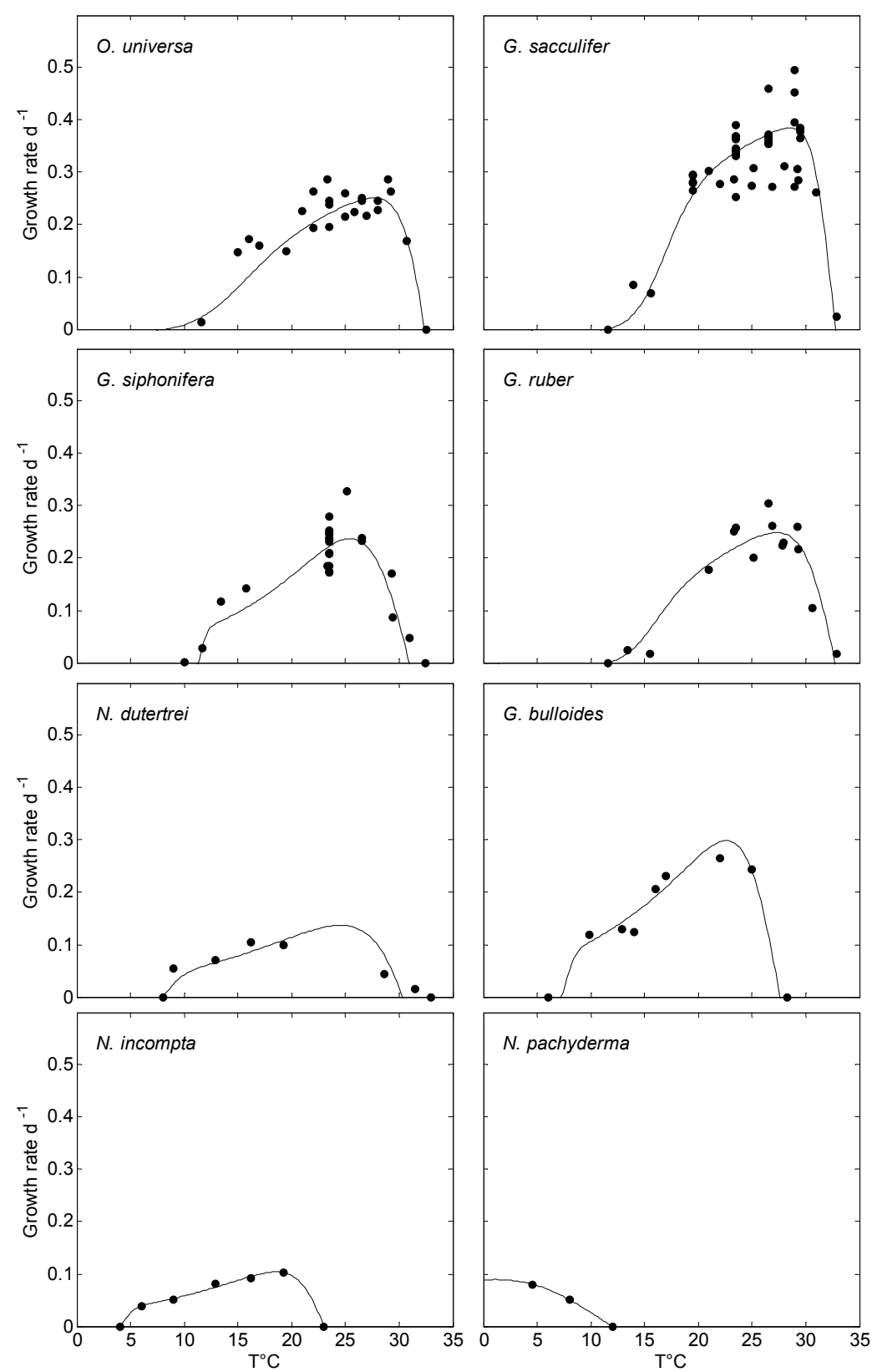

Fig. 1. Observed growth rate in laboratory experiments (Lombard et al., 2009b) for the different species (dots) compared to model outputs (line) after calibration under saturating food and light conditions. Resulting model parameters are listed in Table 2.

et al. (2009b). Because all observations from Lombard et al. (2009b) were conducted within illuminated conditions, we also assume that the mean light intensity corresponding to these observations is near to the saturating light level ( $200 \mu$ mole photon $\mathrm{m}^{-2} \mathrm{~s}^{-1}$ ). Knowing that these data were obtained for specimens fed every day or every two days, and that foraminifer in natural conditions should obtain one prey every 4-5 days (Hemleben et al., 1989), we assumed that these observations correspond to food saturated conditions (i.e. $\left.F /\left(F+k_{\mathrm{n}}\right) \approx 1\right)$ and then the parameter $k_{\mathrm{n}} \operatorname{did}$ not need to be calibrated at this step. The parameters were then estimated by a least square minimisation (Nelder-Mead simplex method) of the overall model compared to the empiric data on growth.

After calibration, by combining nutrition, respiration, and photosynthesis, the model simulates with a high confidence the individual growth pattern for the eight species observed under laboratory conditions (Fig. 1; all coefficient of determination between model simulations and observations are higher than 0.88 , but for $N$. dutertrei; $R^{2}=0.76$ ). Except 
for the half saturation constant for nutrition $k_{\mathrm{n}}$, all the parameters were thus calibrated with culture experiments, and the results for the different parameters are given in Table 2.

\subsection{Species abundance in natural conditions}

\subsection{Strategy: from individual growth rate to population abundance}

Extending individual growth rates to population growth in natural conditions, for the eight different species, using the mechanistic approach, would require precise biological knowledge on feeding preferences, food availability of the different food types, reproduction, and mortality of foraminifers. Not all the necessary information is currently available. Planktic foraminifers feed on various types of food including zooplankton, protozoans, and phytoplankton (Hemleben et al., 1989). However, except of limited in situ observations, the abundance of different prey items is rarely available together with foraminifer observations. The different outputs of a general ecosystem model may be used to solve this issue (e.g. Fraile et al., 2008). However, prey preference of different foraminifer species is only poorly known, and, because of the lack of data, could be calibrated neither with laboratory experiments nor in situ observations. In addition, whereas Chlorophyll- $a(\mathrm{Chl}-a)$ is generally well constrained in ecological models, the other outputs (zooplankton, protozoans, and detritus) are not yet sufficiently constrained. Taking into account these limitations we use the Chl- $a$ concentration as a general productivity indicator, and as food concentration available to foraminifers. This is a reasonable hypothesis knowing that copepods, which are prey of spinose tropical foraminifers (O. universa, G. siphonifera, G. ruber, G. sacculifer; Hemleben et al., 1989), are generally correlated in abundance with Chl- $a$ (Gasol et al., 1997). Non-spinose species are mostly herbivorous or detritivorous (Hemleben et al., 1989) and feed on prey that contains Chl- $a$. Choosing Chl- $a$ as food has different advantages: (1) Plankton net sampling of foraminifers was sometimes conducted together with measurements of Chl- $a$ concentration. The model may therefore be calibrated on real observations. (2) Chl- $a$ is observed by a large number of satellites, which give a confident estimation of food level in the oceans upper meters on a global scale. (3) Chl- $a$ is the best constrained and validated biological variable in global ecosystem models, which gives also confidence in the use of these models. Besides food availability, the other processes necessary to model population growth, mortality, reproduction, and predation, have been studied only in a few cases (Schiebel et al., 1997; Schiebel and Hemleben 2000) and thus are mostly unknown for foraminifers and would need further observations to be calibrated efficiently.

We chose to generalize the model with a progressive adjustment of the half saturation constant for nutrition $\left(k_{\mathrm{n}}\right)$ to get the best model output fit when compared to observed species abundance in plankton multinet samples collected in known conditions. As already discussed, the parameter $k_{\mathrm{n}}$ is the only parameter that we could not calibrate using culture experimental data.

\subsubsection{Calibration data set: multinet data}

The calibration data set includes the results from plankton multinet sampling from different studies (Field, 2004; Kuroyanagi and Kawahata, 2004; Schiebel et al., 2001, 2004; Watkins et al., 1996; 1998). These data include foraminifer counts (ind $\mathrm{m}^{-3}$ ), $T^{\circ} \mathrm{C}$, and Chl- $a$ for each sampled depth. These plankton tows were obtained with mesh size from $63 \mu \mathrm{m}$ (Kuroyanagi and Kawahata, 2004; Watkins et al., 1996, 1998) to $100 \mu \mathrm{m}$ (Schiebel et al., 2001, 2004) and $120 \mu \mathrm{m}$ (Field, 2004). In order to keep the coherence of data, and because juvenile forms of $O$. universa were rarely recognised or counted both in plankton or sediment samples, only adult forms (when indicated) were considered. Only white forms of $G$. ruber were considered because all the laboratory experiments used to calibrate the model were performed on this morphospecies, and, in the Pacific and Indian Ocean, the pink variety is not present.

$N$. pachyderma needed to be considered separately due to the lack of observations with hydrological constraints. We use data from Schiebel (2002) for this species to increase the observed reference database and outputs from a plankton ecological model PISCES (see below) at the corresponding location, season, and depth as a reasonable forcing for the foraminifer growth model in lack of available direct measurements of environmental variables. Data used as forcing input in the model $\left(T^{\circ} \mathrm{K}\right.$, light intensity, and food concentrations) correspond to the same geographical position and same month as the foraminifer collection.

For all data sets, observed Chl- $a$ (mg Chl- $\left.a \mathrm{~m}^{-3}\right)$ concentration was converted to carbon biomass $\left(\mathrm{mgC} \mathrm{m}^{-3}\right)$ by using a variable C:Chl- $a$ factor that depends on temperature, light, and nutrient availability (Taylor et al., 1997) as successfully modelled by Geider et al. (1997). To apply this conversion we used outputs of the PISCES model (Aumont et al., 2003; Aumont and Bopp, 2006), which implement the Geider et al. (1997) model on a global scale in order to supply a realistic $\mathrm{C}$ : Chl- $a$ ratio that takes into account the effect of seasons and hydrology.

Light intensity data were obtained from SeaWIFS satellite data for the corresponding date of sampling. Light intensity at depth $z\left(\mathrm{PAR}_{z}\right)$ was calculated from intensity measured at the sea surface and taking into account the observed Chl- $a$ concentration in seawater assuming the following relationship:

$\operatorname{PAR}_{z}=\operatorname{PAR}_{z-1} \exp \left(z\left(-K_{\mathrm{dw}}-K_{\mathrm{dc}}[\mathrm{Chl}-a]\right)\right)$

where $K_{\mathrm{dw}}$ is the diffuse attenuation coefficient for water alone, estimated around $0.038 \mathrm{~m}^{2}$ by Lorenzen (1972), and $K_{\mathrm{dc}}$ is the specific attenuation coefficient due 
to Chlorophyll- $a$ estimated around $0.016 \mathrm{~m}^{2}$ (mg Chl$a)^{-1}$ (Gallegos and Moore, 2000).

Daylength (dl) was calculated by taking into account latitude and date using the Forsythe et al. (1995) model.

\subsubsection{FORAMCLIM model calibration}

When using the growth model $\left(k_{\mathrm{n}}\right.$ unconstrained) to simulate growth under natural conditions, a general positive correlation was observed between the estimated growth rate and the observed abundance of each species. Thus, our results may indicate a close coupling between individual growth rate and population abundance. In the present case, close coupling between individual growth rates and population abundance of foraminifers could have different origins: (??) the low density of the populations (foraminifers generally occur in low abundance compared to other plankton organisms), which means that the environment rarely becomes saturated by foraminifer and competition for resources does not exist and implies no specific predators. (2) The high mortality rate, both during the life cycle and following reproduction (foraminifers decease after liberation of gametes; Hemleben et al., 1989). (3) A low efficiency of reproduction, especially when growth rates are low. These characteristics specific for foraminifers could induce a short resilience time of populations when conditions are unfavourable, and indicate close coupling between growth rates (controlled by environmental factors) and abundance, with only a small lag between the timing of maximum growth rate and maximum abundance (Fig. 2). If the mismatch would be larger, no correlations would have been observed.

This suggests that the growth rate estimated for each foraminifer species can be used as an abundance indicator. Taking into account these considerations, we tested the hypothesis that the correlation between growth rate $(\mu)$ and abundance (Abund) follows an exponential relationship with a minimal abundance $\left(0.1\right.$ ind $\left.\mathrm{m}^{-3}\right)$ for all species when $\mu$ is null and in the form:

Abund $=a \mu^{b}-a+0.1$

In spite of the potential problems, and/or over-simplification of such an approach, we thus decided to use the observed correlation between population density and individual growth rate to model abundance based on food (Chl- $a$ ) availability, light, and temperature. It is important to note that the transformation from growth rate to abundance represents only an ideal foraminiferal community with a mean potential abundance. This is the only way presently available to represent foraminifer abundance without simulating their population dynamics which would have dramatically increased the model complexity and introduce many unknown processes that are not enough studied yet (mortality, reproduction, predation).

For each species, the half saturation constant for nutrition $\left(k_{\mathrm{n}}\right)$ was calibrated in order to maximise the correla-
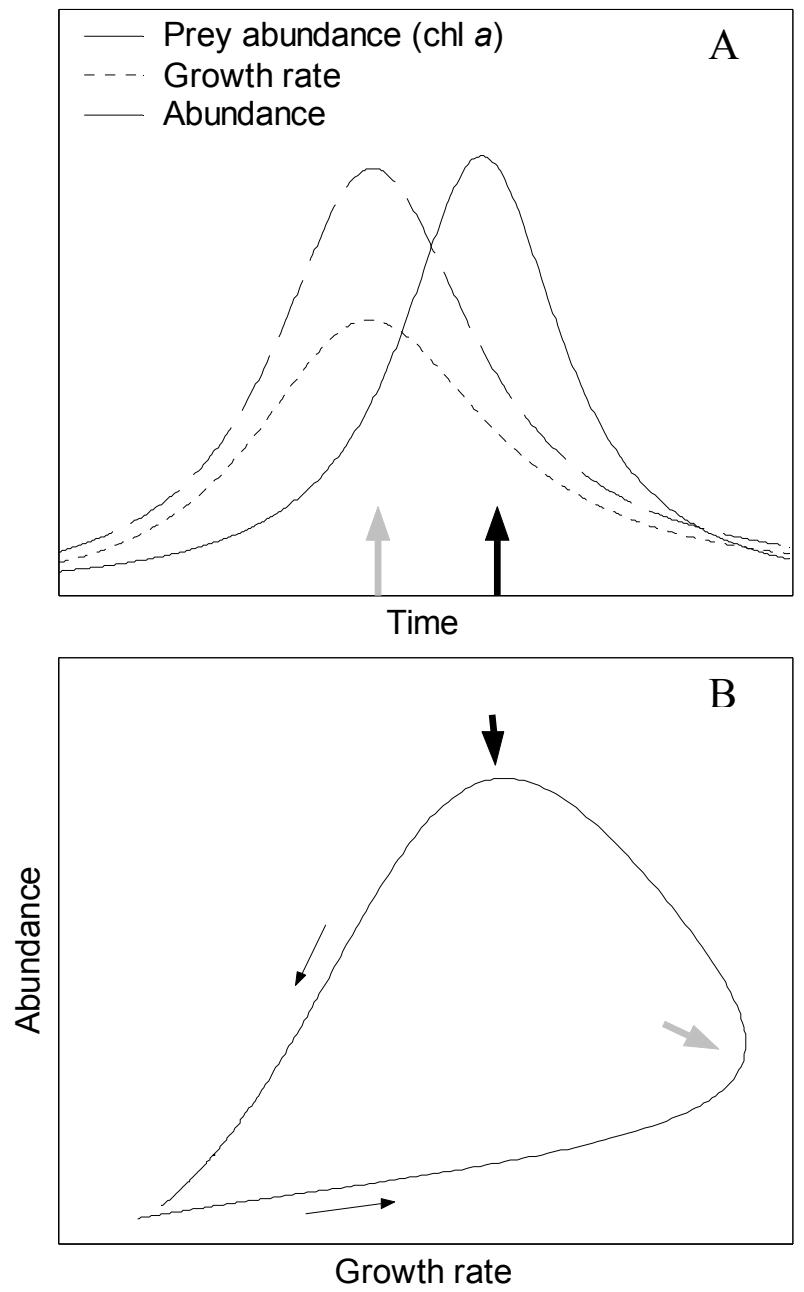

Fig. 2. Schematic explanation of the potential reasons of the growth rate-abundance coupling. (A) When prey abundance is high, individual growth rate is maximal (grey arrow) but there is a time lag between maximum individual growth rate and observed population abundance maximum (black arrow). When this time lag between maximum growth rate and maximum abundance is small, then a potential coupling between growth rate and abundance thus may be observed $(\mathbf{B})$ in which the variability is due to the time lag. The small black arrows represent the time course of an assemblage development.

tion between the model individual growth rate $\mu$ and species abundance Abund (i.e., increase $R^{2}$ of the correlation) in the multinet data.

After calibration, the (7) relationship for which the correlation was maximised is used to transform model growth rate into abundance data. When $\mu$ is negative the species abundance is set to zero. The correlation between abundance and growth rate is shown in Fig. 3. The parameters $k_{\mathrm{n}}, a$, and $b$ are listed in Table 2 for the different species. Due to the scarcity of data on adult $O$. universa, the relationship between growth rate and abundance is weak $\left(R^{2}=0.017 ; F_{\text {stat }}\right.$ 

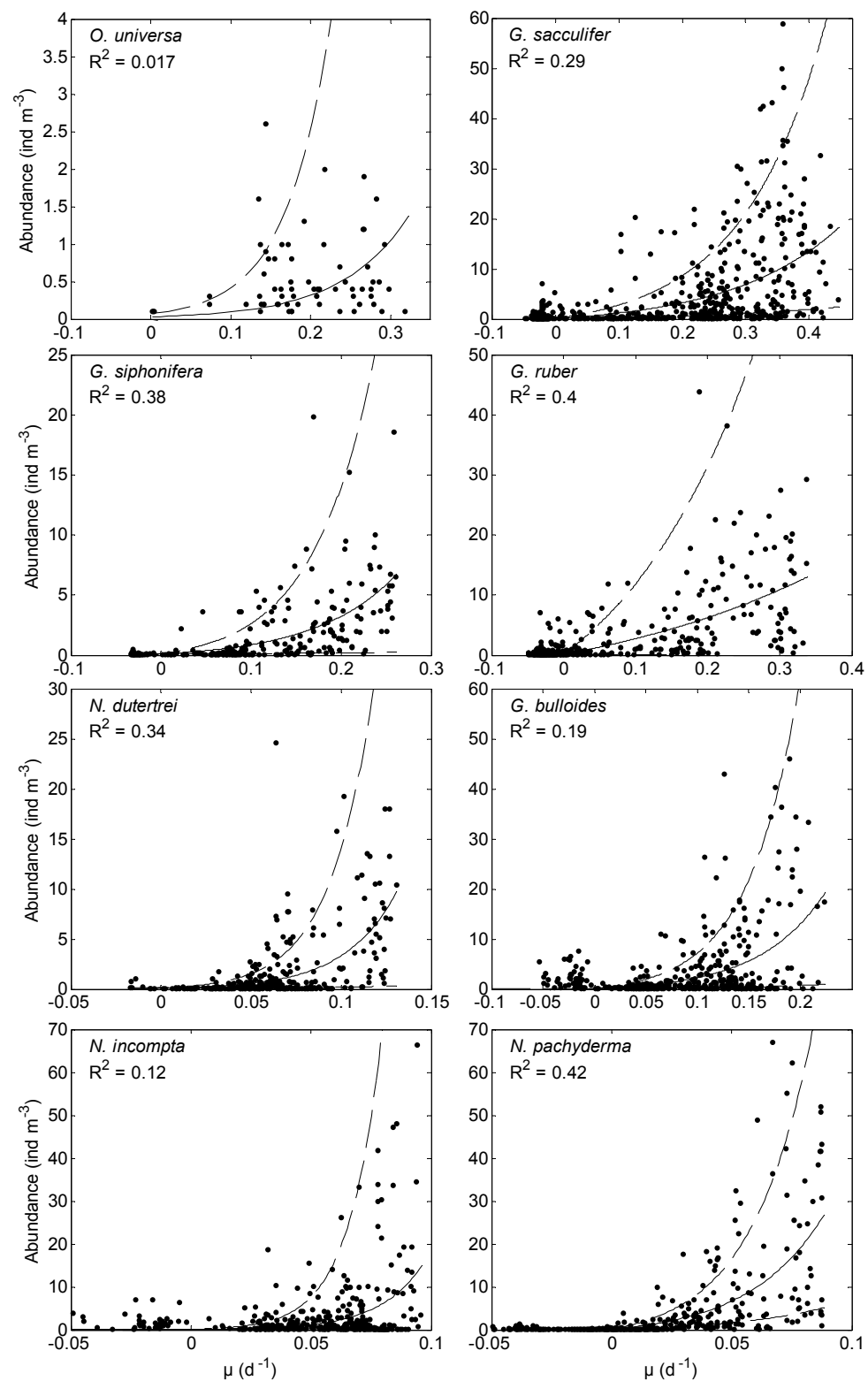

Fig. 3. Observed coupling between observed abundance in multinets samples and model-estimated growth rate $(\mu)$ after calibration of the parameter $\mathrm{kn}$. The fit of each relationship between growth rate and abundance (black line) is indicated (see Table 2 for parameters) as well as the $95 \%$ confidence limits (dashed line).

$=7.01 ; 0.05>p>0.01)$. For the other species, the relationships are highly significant (all $F_{\text {stat }}$ with $p<0.001$ ) despite the large scattering attributed to the small mismatch between the maximum of growth and of abundance (see Fig. 2), The relationship between abundance and modelled growth rate is relatively strong for $G$. sacculifer $\left(R^{2}=0.29\right), G$. siphonifera $\left(R^{2}=0.38\right), G$. ruber $\left(R^{2}=0.4\right), N$. dutertrei $\left(R^{2}=0.34\right)$ and $N$. pachyderma $\left(R^{2}=0.42\right)$, and lower for $G$. bulloides and $N$. incompta ( $R^{2}$ respectively 0.19 and 0.12 ). This is probably attributable to scarce abundance data of these two species under conditions where the modelled growth rate is negative.
These observations generally correspond to subsurface waters where food is scarce and temperature low, and conditions do not allow significant growth of these species. In fact, the observed foraminifers could originate from individuals that grew under near surface conditions, where the model simulates positive growth, and afterward have been transported to depth both by sinking or advection, process the model cannot reproduce so far. 


\subsubsection{Model evaluation}

In order to validate the model, we tested and compared its results with data bases covering large areas, i.e., foraminifer species dominance from sea surface plankton tows, and foraminifer species proportion in sediment core tops.

Foraminifer total abundance and species dominance (i.e. species having the highest abundance in the foraminiferal assemblage) in sea surface plankton tows $(0-10 \mathrm{~m})$ were recovered from Bé and Tolderlund (1971). This study covers the entire Atlantic and Indian Oceans. These data correspond to more than 10 multi-station cruises in different years and seasons. In order to simplify the procedure, we did not determined the sampling season of each sampling point but simply assumed that the dataset represents an annual average of species dominance. In order to simulate these observations with the model, annual means from satellite images from MODIS ( $T^{\circ} \mathrm{C}$, Chl- $a$ ) and SeaWIFS (Photosyntheticaly Active Radiations, PAR, $\mu$ mole photon $\mathrm{m}^{-2} \mathrm{~s}^{-1}$ ) were used (http://oceancolor.gsfc.nasa.gov/). Annual means of sea surface results ( $T^{\circ} \mathrm{C}$, Chl- $a$, and PAR) of the general ecosystem model (PISCES model; Aumont and Bopp, 2006) were alternatively used to simulate foraminiferal abundance (annual mean, $0-10 \mathrm{~m}$ depth). To do so, we used the standard climatological simulation of PISCES as described and evaluated in Aumont and Bopp (2006). By using the mean annual $T^{\circ} \mathrm{C}$, Chl- $a$, and PAR observed by satellites (mean annual sea surface conditions), the growth rates of the different species were calculated and converted to abundance data using the growth rate-abundance relationships (Fig. 3). These results were then used to estimate species dominance (i.e. species with the highest abundance). In order to compare the model simulation to the data of Bé and Tolderlund (1971), we assume that if the dominant species is the same in both model simulation and data, the model result is correct. However, for some observations it was not possible to determine which species dominate the assemblage and a co-dominance was attributed to those observations (Fig. 4a). Because the model results cannot gives such an exact co-dominance, the model was assumed correct if one of the two observed codominants species was reproduced.

Results from core tops foraminifer counts (MARGO database; Barrows and Juggins, 2005; Hayes et al., 2005; Kucera et al., 2005) were also used. This database includes around 3000 samples covering all oceans. Abundance data were converted to relative abundance by considering only the eight species included in the model. Shannon diversity index $\left(H^{\prime}\right)$ was calculated from species relative abundances of the eight considered species, $\left(p_{i}\right)$, both from the model and from core tops data, by using the following relationship:

$H^{\prime}=-\sum p_{i} \log \left(p_{i}\right)$

In order to simulate an equivalence to core tops assemblages, the model was run with two different data sets. Firstly, the model was run using mean monthly $\mathrm{Chl}-a, T^{\circ} \mathrm{C}$, and PAR

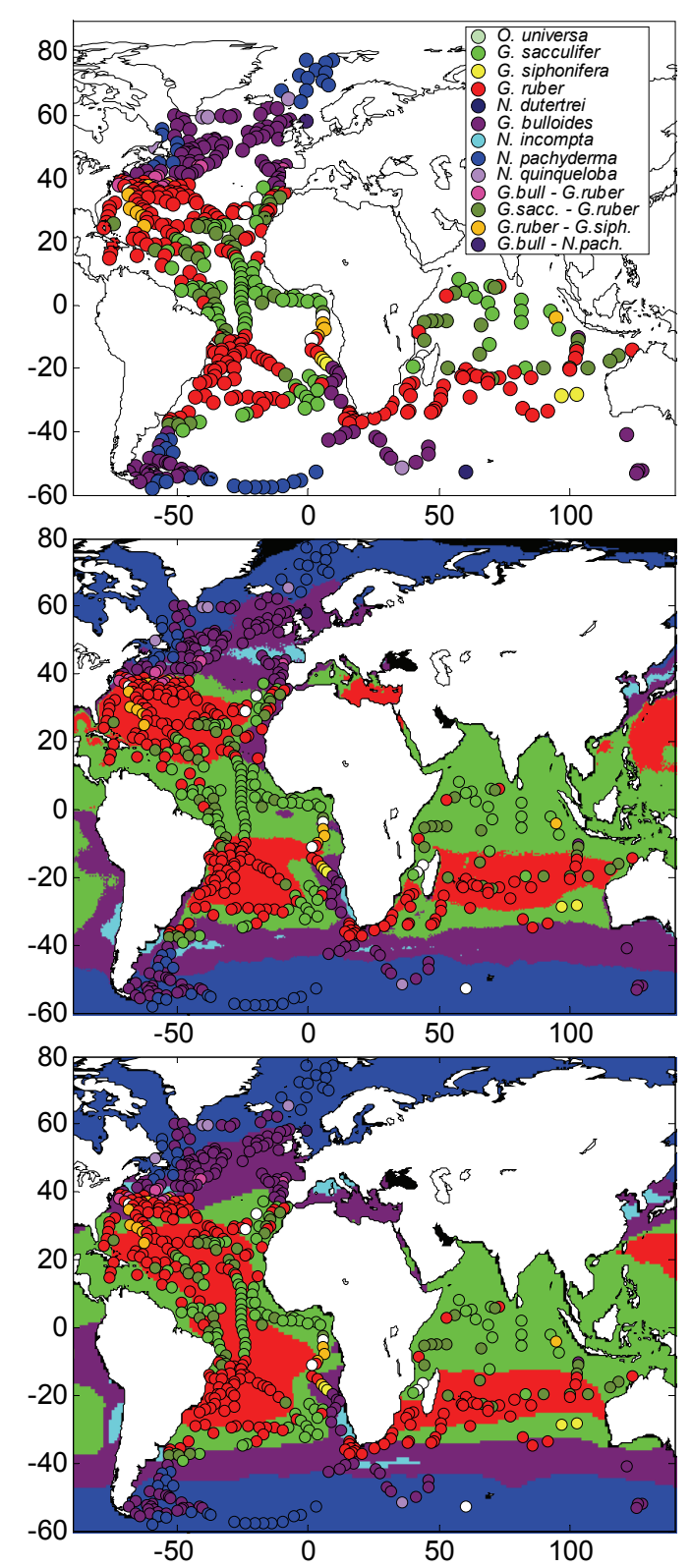

Fig. 4. (Upper panel) Dominant species observed by Bé and Tolderlund (1971) within sea surface conditions (upper $10 \mathrm{~m}$ ). Each colour represents a different dominant species assemblage (see key for the colour code). Dominant species simulated by the model (background colours) in surface conditions (annual average) by using satellite images (middle panel) or PISCES model (lower panel) as inputs. The model reproduces $70.5 \%$ of the 576 observations when using satellite images and $58.9 \%$ using PISCES model.

observations derived from satellite images (monthly averages). The abundance of each species was cumulated over months to produce a mean annual estimate and expressed as a fraction $\left(p_{i}\right)$ of the total foraminifer abundance and $H^{\prime}$ was calculated following Eq. (8). Secondly, the model was forced by outputs from the PISCES model. Monthly $T^{\circ} \mathrm{C}$, PAR, 
and Chl- $a$ average were used in a similar way as for satellite data, and their distribution within the upper $200 \mathrm{~m}$ of water column simulated by the PISCES model. Abundances of the different species were cumulated with reference to month and water depth.

For all core tops data, deviations between the $n$ observed $\left(x_{\mathrm{o}}\right)$ and modelled $\left(x_{\mathrm{m}}\right)$ species relative abundance were calculated using coefficient of determination $\left(R^{2}\right)$ and, in order to compare with previous studies, with the root mean squared error (RMSE) which is calculated as follow:

$\mathrm{RMSE}=\sqrt{\frac{\sum_{i=1}^{n}\left(x_{\mathrm{oi}}^{-} x_{\mathrm{mi}}\right)^{2}}{n}}$

These monthly simulations were also used to determine the season and water depth of maximum growth (i.e. season or water depth where the growth rate is maximum in the model) for the different species.

\section{Results}

\subsection{Species dominance}

The model successfully reproduces species dominance of foraminifer observed in Atlantic and Indian Oceans by sea surface plankton tows (Bé and Tolderlund, 1971; Fig. 4), with $70.5 \%$ of the 576 observations being correctly estimated by the model (Fig. 4). The model reproduces the general biogeography of dominant foraminifers, with $G$. ruber dominating in oligotrophic tropical gyres. G. sacculifer dominates in the equatorial area, in the North Indian Ocean and at the limits of temperate regions, except of the Gulf Stream where the assemblage shifts from a $G$. ruber dominance to $G$. bulloides without transition. G. bulloides dominates the species assemblage in temperate regions and also in some tropical coastal productive areas such as in the Benguela and Mauritanian upwelling regions. In few locations, $N$. incompta is modelled as the dominant species notably close to the coast in the southern part of the Benguela upwelling system, along the Uruguay coast, and in the northeast of the Atlantic Ocean around $45^{\circ}$ N. N. pachyderma dominates the ecosystem in polar regions starting from $50^{\circ} \mathrm{S}$ latitude in the Southern Hemisphere, and from the Canadian coast to Iceland and Norway in the North Atlantic Ocean.

Using the environmental results of the PISCES model (mean annual sea surface conditions), our model simulates a similar geographic distribution in the dominance of the different species, but with lower confidence $(58.9 \%$ efficiency; Fig. 4). Most of these differences come from the fact that the PISCES model uses a $2^{\circ}$ mesh grid, which does not allow reproduction with sufficient confidence of fine scale physical processes such as the Gulf Stream or the equatorial Atlantic upwelling, and most of the discrepancies between observed and modelled dominances are observed here. For example, in the equatorial Atlantic, the food concentration is slightly lower than observed by satellite images, which results in $G$. ruber dominance instead of $G$. sacculifer. The Gulf Stream region is not sufficiently contrasted hydrographically. Then the model simulates a gradual change in dominance from $G$. ruber to G. sacculifer and then to $G$. bulloides rather than the observed direct transition from $G$. ruber to G. bulloides. However, excepted for these two locations that were massively sampled, the general pattern of species dominance is correctly reproduced.

\subsection{Total abundance in surface waters}

The general abundance of foraminifers under different sea surface conditions is simulated by combining the abundance of all the species simulated by the model when forced by satellite derived data. This abundance may be compared to observations of Bé and Tolderlund (1971) (Fig. 5), but with caution. Bé and Tolderlund (1971) reported only three classes of abundance, and used a $200 \mu \mathrm{m}$ mesh sized plankton tow whereas our model abundance has been calibrated for $64-120 \mu \mathrm{m}$ mesh size multinet sampling. The range of abundance simulated by the model $\left(0-80\right.$ ind $\mathrm{m}^{-3}$; Fig. 5) is in the same range as that observed in Atlantic and Indian Oceans $\left(0-100\right.$ ind $\left.\mathrm{m}^{-3}\right)$. The pattern of abundance of foraminifer species is reproduced by the model with a maximum abundance in the equatorial regions, African upwelling, Arabian Sea, off Uruguay and the Brazil coast, and in the Gulf Stream. Considering the Gulf Stream and the southern Indian Ocean, the simulated maximum abundance is less extended towards the poles than observed.

These differences may have two origins. Firstly, we used mean annual observations to force the model, whereas Bé and Tolderlund (1971) report data from different seasons. Indeed, foraminifer sampling in the subpolar Atlantic and Indian Ocean, correspond generally to summer conditions when the foraminifer abundance is higher than simulated by annual mean conditions. Secondly, the model, derived from available laboratory observations, simulates the abundance of eight of the most abundant species in the world ocean, but misses some of the species which are significant in polar and temperate regions such as Turborotalita quiqueloba, Globorotalia inflata and Globigerinita glutinata. Those were included in Bé and Tolderlund (1971) observations and contribute to a significant fraction of foraminifer assemblage in transitional region. This could explain the smaller poleward extension of the modelled maximum abundance in the Atlantic and Indian than observed by Bé and Tolderlund (1971).

\subsection{Relative abundance of the species}

Comparison of the simulation data with core tops foraminiferal assemblages from the MARGO data base (Barrows and Juggins, 2005; Hayes et al., 2005; Kucera et al., 2005), recalculated on the basis of eight species, are shown 

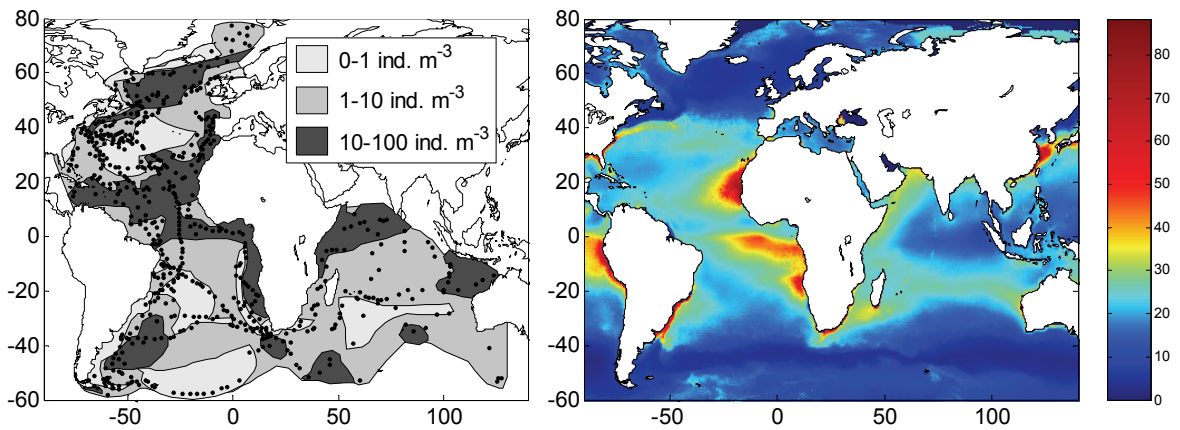

Fig. 5. Total $>200 \mu \mathrm{m}$ foraminifer abundance (ind $\mathrm{m}^{-3}$ ) observed within sea surface conditions (Bé and Tolderlund, 1971; left panel) and simulated by the model (right panel) under sea surface condition by using satellite images (annual average).

Table 3. Coefficient of determination $\left(R^{2}\right)$ and in parenthesis, root mean squared error (RMSE) obtained between observed core tops relative abundance of the different foraminifer species and results of the models. Different subsets were used: the whole - worldwide dataset or a subset focused on the Atlantic Ocean. Both results originating from model simulation using satellites subsurface data, that take only seasonality in consideration, or the PISCES model results (data not showed), that take both seasonality and depth in consideration, as forcing variables for the simulation are indicated.

\begin{tabular}{lrrrrrrrr}
\hline & \multicolumn{3}{c}{$\begin{array}{c}\text { Satellite images (Seasons) } \\
\text { Worldwide }\end{array}$} & \multicolumn{2}{c}{ Atlantic } & \multicolumn{3}{c}{ PISCES (Seasons and depth) } \\
& \multicolumn{2}{c}{ Worldwide } & \multicolumn{2}{c}{ Atlantic } \\
\hline O. universa & 0.07 & $(3.28)$ & 0.11 & $(2.78)$ & 0.07 & $(3.24)$ & 0.12 & $(2.64)$ \\
G. sacculifer & 0.56 & $(17.46)$ & 0.65 & $(12.61)$ & 0.56 & $(12.38)$ & 0.58 & $(9.94)$ \\
G. siphonifera & 0.43 & $(6.00)$ & 0.55 & $(5.11)$ & 0.42 & $(5.29)$ & 0.54 & $(4.61)$ \\
G. ruber & 0.46 & $(17.76)$ & 0.52 & $(16.49)$ & 0.37 & $(23.14)$ & 0.39 & $(21.78)$ \\
N. dutertrei & 0.09 & $(17.23)$ & 0.21 & $(11.82)$ & 0.16 & $(17.53)$ & 0.34 & $(13.64)$ \\
G. bulloides & 0.37 & $(18.97)$ & 0.57 & $(13.16)$ & 0.28 & $(21.02)$ & 0.37 & $(16.47)$ \\
N. incompta & 0.39 & $(14.85)$ & 0.40 & $(17.95)$ & 0.31 & $(15.85)$ & 0.28 & $(19.97)$ \\
$N$. pachyderma & 0.85 & $(12.32)$ & 0.84 & $(13.70)$ & 0.81 & $(17.04)$ & 0.80 & $(19.37)$ \\
\hline Diversity & 0.50 & $(0.52)$ & 0.59 & $(0.43)$ & 0.58 & $(0.48)$ & 0.69 & $(0.45)$ \\
\hline
\end{tabular}

in Figs. 6 and 7. The model fit is expressed by the coefficient of determination $\left(R^{2}\right.$; Table 3$)$ which represent the fraction of data variability explained by the model. The $R^{2}$ are shown for the standard simulation (i.e. worldwide dataset using satellite data Figs. 6-7), and for similar simulations done with the PISCES model considering the effect of water depth and season. We also considered a subset of the data focussing on Atlantic Ocean where the data are more numerous.

The $R^{2}$ on the standard simulation is comprised between 0.07 and $0.85 \%$ for $O$. univers $a$ and $N$. pachyderma, respectively, (Table 3), with variations between species that reflects the $R^{2}$ variations of the fit between estimated growth rate and abundance in multinet samplings (Fig. 2). The model does not efficiently reproduce $O$. universa and $N$. dutertrei spatial variations on a worldwide coverage and only explains $7-9 \%$ of the data variability. The model explains between $37 \%$ (G. bulloides) to $85 \%$ (N. pachyderma) of species relative abundance variations, with most species in the $40-55 \%$ range. When focussing only on the Atlantic Ocean, the $R^{2}$ for all the species is higher than for worldwide comparison, indicating smaller differences between simulated and sampled relative abundance, except for $N$. pachyderma for which the $R^{2}$ remains mostly unchanged. In the Atlantic Ocean, the model better reproduce the spatial variations of $O$. universa (11\% variability explained) and $N$. dutertrei $(20 \%)$. Using data that combine seasonal and depths effects, the PISCES model outputs give results in the same range of order, except for $N$. dutertrei, for which the precision is significantly increased (16\% of variability explained worldwide; $34 \%$ in the Atlantic Ocean).

From a qualitative point of view, the spatial distribution pattern of different species is well represented by the model. As most of the sampling points are concentrated in the Atlantic and Indian Oceans, we focus the description of the spatial distribution patterns to these regions by highlighting the correspondences between the model and observations. $N$. pachyderma is present with high abundance south of $55^{\circ} \mathrm{S}$ latitude and north of $45^{\circ} \mathrm{N}$ in the Pacific Ocean, 

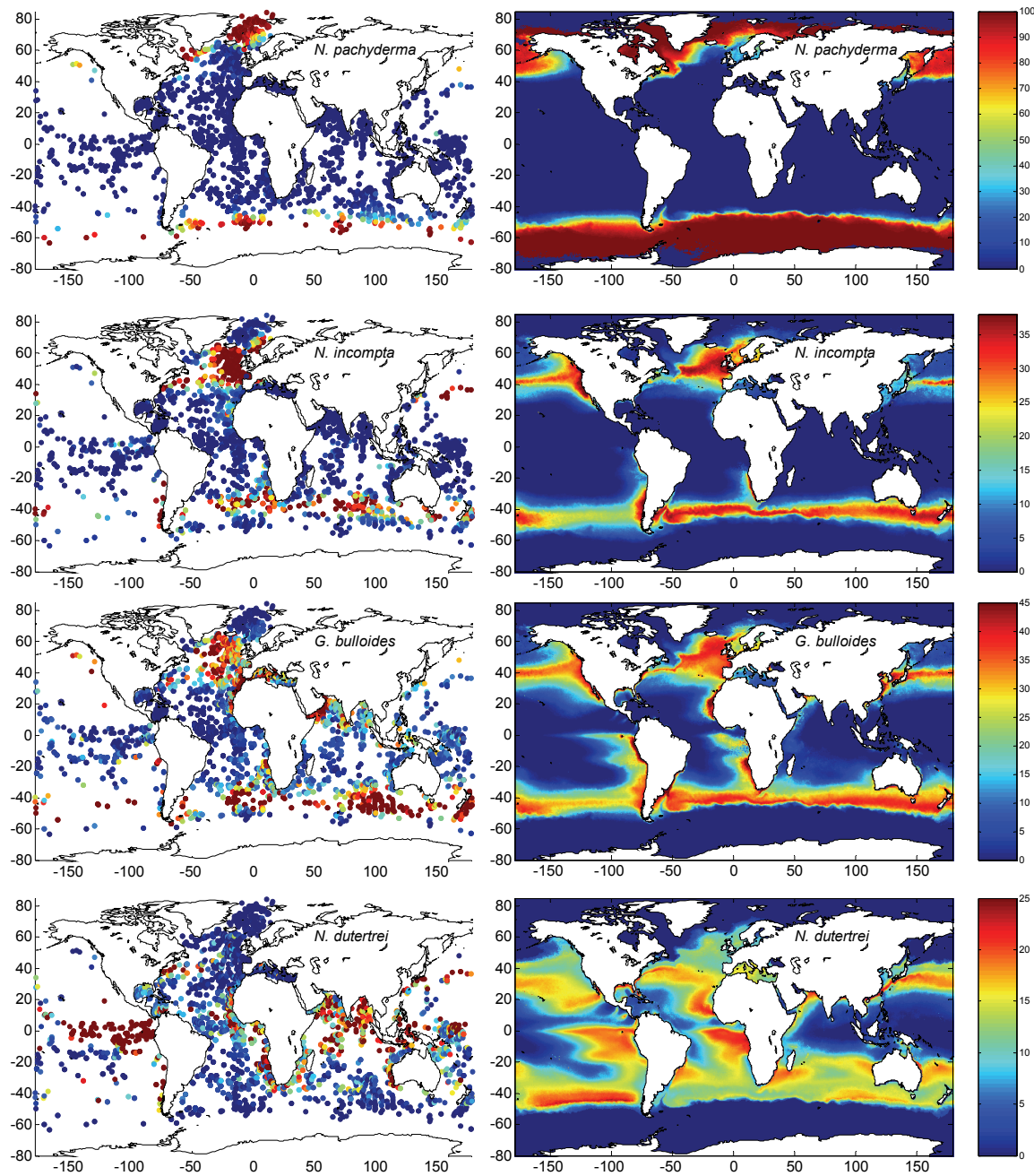

Fig. 6. Relative foraminifer abundance (\%) of the different species observed in core tops samples (left panel) calculated on the basis of the eight selected species and estimated by the model (right panel) using satellite images (monthly averages). Root mean squared error (RMSE) calculated between model simulation and estimations are given in Table 3.

and in the Atlantic Ocean from Labrador Sea to Iceland and Cape North. N. incompta is abundant in the north-western Atlantic Ocean from a narrow zone in the northern part of the Gulf Stream and in the north-eastern Atlantic Ocean to a zone from Gibraltar to Iceland. Low N. incompta abundance is also correctly modelled for the north-western part of the Mediterranean Sea. N. incompta is present in the Southern Hemisphere in a circumpolar belt from $40^{\circ} \mathrm{S}$ to $50^{\circ} \mathrm{S}$, and also in some upwelling zones (Benguela, Argentina and to a lesser extend the Mauritanian upwelling). The spatial distribution of $G$. bulloides is relatively similar to $N$. incompta, but is also present to a larger extent in some tropical upwelling such as Mauritanian, Peru, and the Arabian Sea. N. dutertrei shows high relative abundance in tropical-productive areas such as the southern part of the Gulf Stream, the Arabian Sea, and equatorial upwelling. G. ruber is present mostly in oligotrophic tropical gyres, and is less abundant in productive areas such as coastal and equatorial upwellings. It is also present in the eastern basin of Mediterranean Sea. $G$. siphonifera has a distribution intermediate between $G$. ruber and N. dutertrei. G. siphonifera species is present in oligotrophic areas but shows its maximum relative abundance at the limit between oligotrophic areas and tropical upwelling systems. G. sacculifer shows maximum abundance in a circum-equatorial belt between $20^{\circ} \mathrm{N}$ and $20^{\circ}$ S. O. universa occurs at low abundance from $50^{\circ} \mathrm{N}$ to $50^{\circ} \mathrm{S}$ of latitude.

The relative abundance of different species is in general also well reproduced by the model. However, some regional discrepancies can be observed between modelled and observed relative abundance. For $N$. incompta, the model simulates maximum relative abundance around $35 \%$ in the North Atlantic Ocean whereas it is higher $(\approx 55 \%)$ in observations. 

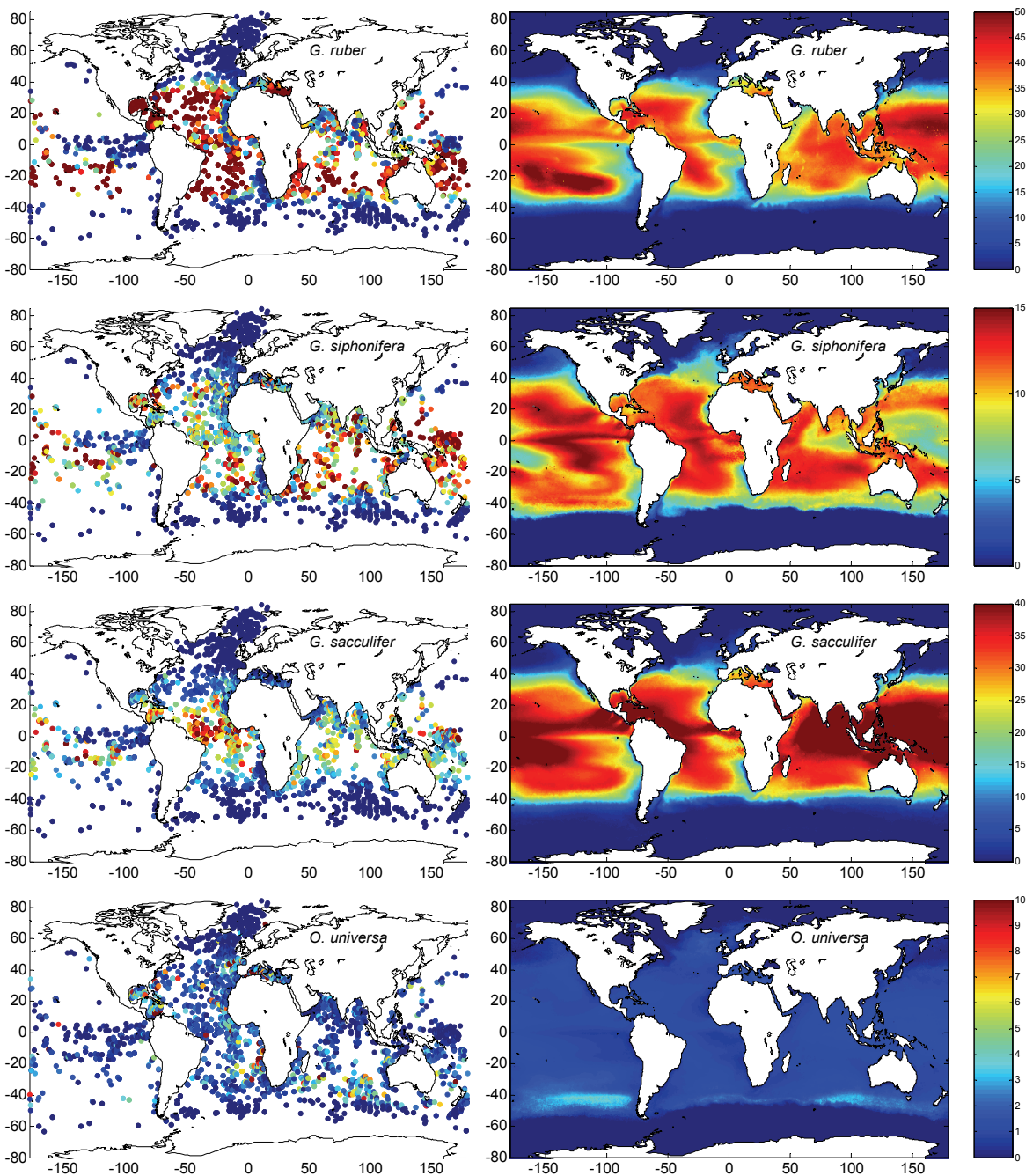

Fig. 7. Same as Fig. 6.

For $G$. bulloides, the modelled relative abundance in the South Atlantic and Indian Oceans is less important than observed. For $N$. dutertrei, the model underestimates the relative abundance in the Arabian Sea, the Bay of Bengal, and in the East Pacific equatorial upwelling whereas it overestimates it in temperate regions. For G. ruber, the relative abundance seems to be slightly overestimated by the model in highly oligotrophic regions, while $G$. sacculifer and $G$. siphonifera are underestimated.

To some extent, these discrepancies could be explained by differences between sea surface conditions (observed by satellite images) and favourable conditions in subsurface waters that satellite images can not observe. Some of these discrepancies are reduced by the use of the PISCES model, which integrates both water depths and seasons, rather than satellite images as forcing variables. However, as seen previously, some small scale events are less efficiently reproduced. For example, using PISCES data reduces the bias for the high abundance of $N$. dutertrei in Arabian Sean, Bay of Bengal and East Pacific equatorial upwelling but do not efficiently capture small scale processes.

\subsection{Diversity}

The Shannon Diversity index is calculated on both core tops data and model outputs considering only the eight selected species (Fig. 8). The modelled diversity pattern corresponds well to the observations $\left(R^{2}=0.50\right)$, especially in the Atlantic Ocean $\left(R^{2}=0.52\right)$ with minimum diversity in polar regions and in the centre of the subtropical oligotrophic gyres. Maximum diversity was calculated at the southern limit of the Gulf Stream, off the west coast of Africa, and in the circumpolar belt around $40^{\circ} \mathrm{S}$ of latitude, and intermediate diversity in the equatorial part of the Atlantic Ocean. However, some discrepancies can be observed such as the high diversity in the central part of the Indian Ocean, and the low 

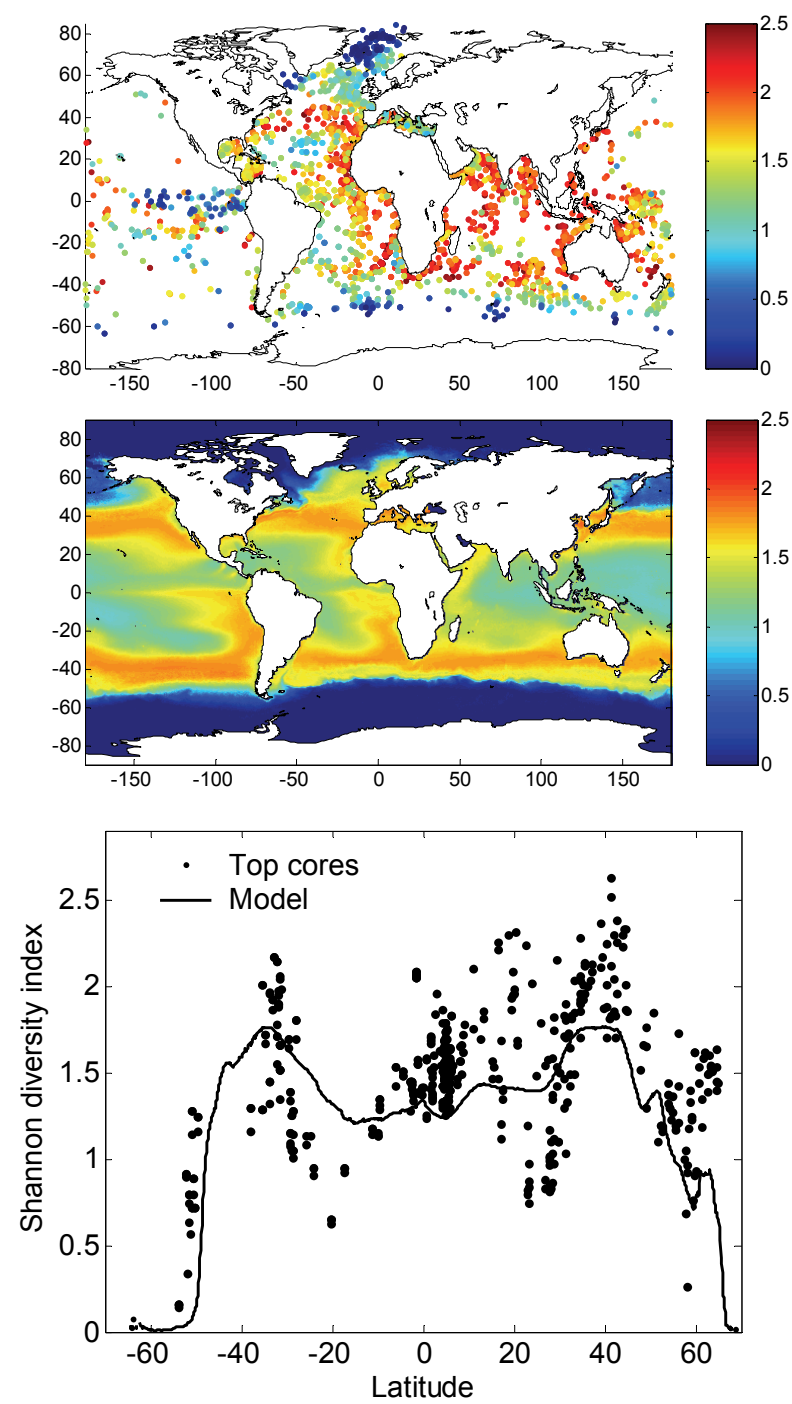

Fig. 8. Shannon diversity index calculated from core tops data using the eight selected species (upper panel) and simulated by the model (middle panel) by using satellite images. Mean model results (lower panel, line) and observations (dots) in the $40^{\circ}$ $-20^{\circ} \mathrm{W}$ (Mid Atlantic Ocean) where extracted for a better comparison. Root mean squared error (RMSE) calculated between model simulation and estimations are given in Table 3.

diversity $(<1)$ in the equatorial Eastern Pacific, due to a high abundances of $N$. dutertrei, which are not reproduced by the model (see Fig. 6).

The mean modelled and observed diversity was extracted in a mid Atlantic transect between $25^{\circ} \mathrm{W}$ and $50^{\circ} \mathrm{W}$. The model simulates well the diversity pattern with maximum values at $40^{\circ}$ north and south, a sharp decrease in diversity in polar regions around $50^{\circ} \mathrm{S}$ and more gradually in the northern hemisphere, a minimum diversity in subtropical gyres $\left(20^{\circ} \mathrm{S}\right.$ and $\left.20^{\circ} \mathrm{N}\right)$, and an intermediate diversity around the equator.
However the model seems to smooth the variations in diversity by simulating lower amplitude changes over different regions. In high diversity regions, the model slightly underestimates the diversity whereas it overestimates it in tropical gyres. Using the PISCES model (including species variations with depth) rather than the satellite images as input data for the model gives similar results but with better adequacy with the data (Table $3 ; R^{2} 0.58-0.69$ for worldwide and Atlantic simulation, respectively).

\subsection{Model predictions on season and water depth of maximum growth}

In order to estimate the season and depth of the maximum growth potential, and consequently abundance, the model was run using PISCES model outputs combining depths and seasons in order to determine in which season and water depth the maximum of growth potential occurs. For G. sacculifer, G. siphonifera, G. ruber, and O. universa the simulation indicates that maximum abundance should systematically be observed in surface waters (0-10 m; data not shown). In this case, we used preferentially satellite images to simulate the influence of seasons (Fig. 9). These four species approximately show the same pattern in their seasonal preferences with maximum growth in August in the northern temperate oceans, in May-June in the western part of north tropical oceans, and in August-September in the eastern part north tropical oceans. In equatorial waters, maximum growth is modelled for October, and from February to March in the tropical and temperate southern marine ecosystems.

For the other species (N. dutertrei, G. bulloides, N. incompta and N. pachyderma), maximum abundance could occur at depths, and we used PISCES data to determine the combined depth and season of maximum growth (Fig. 10). For $N$. dutertrei, maximum growth rates were modelled in surface waters for summer in the $30-60^{\circ}$ latitude (JulyAugust and February-March for the Northern and Southern Hemisphere, respectively). At the $0-30^{\circ}$ latitude range, $N$. dutertrei occurs mostly in spring and exhibits maximum growth at sub-surface waters around $60-80 \mathrm{~m}$ and deeper $(>100 \mathrm{~m})$ in oligotrophic gyres. N. incompta and $N$. bulloides have similar seasonal growth patterns with maximum growth in summer at the $60--40^{\circ}$ latitude and maximum in spring in subtropical and tropical areas. Their depth of maximum growth also progressively increases while the waters become more oligotrophic at the surface, and $N$. incompta exhibits generally larger depth of maximum growth than G. bulloides. N. pachyderma has its maximum growth ability in spring in the $40-60^{\circ}$ latitude range and in early summer in higher latitudes. The maximum growth potential is always in surface waters in the North Atlantic Ocean whereas a progressive increase in depth is observed in the northeastern Pacific Ocean. In the Southern Ocean, $N$. pachyderma maximum growth rate is always located in sub-surface waters between $20-30 \mathrm{~m}$ in $80-60^{\circ} \mathrm{S}$ latitudes 


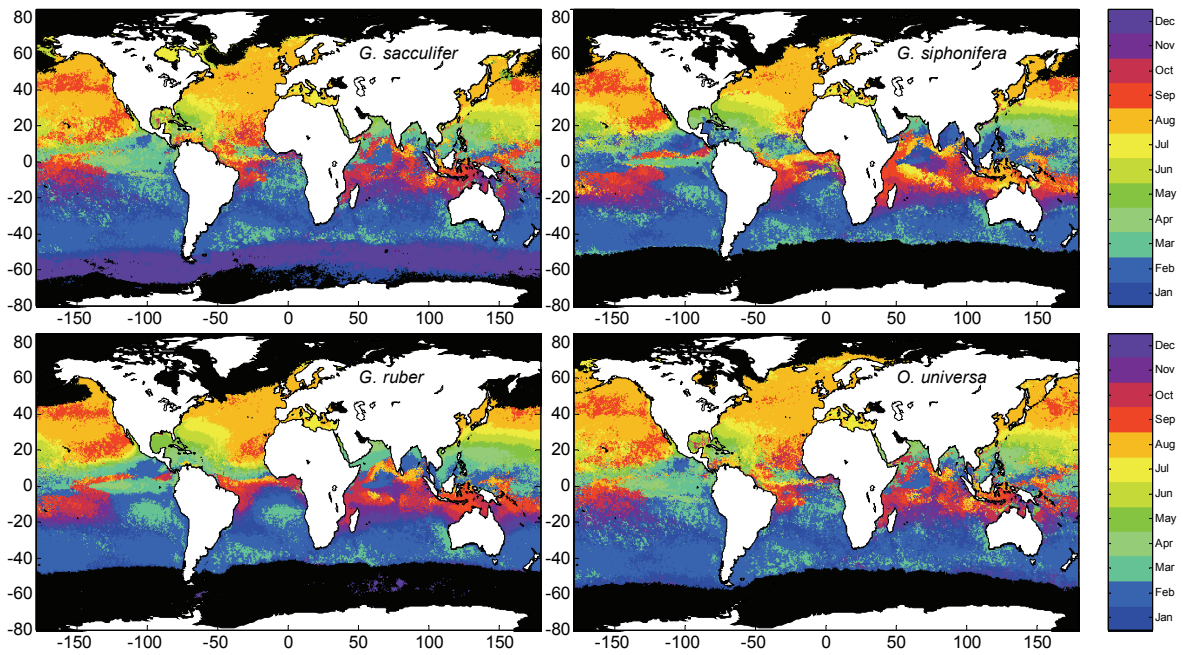

Fig. 9. Estimated season of maximum growth rate for G. sacculifer, G. siphonifera, G. ruber and O. universa. These species have been estimated to mainly live within the $0-10 \mathrm{~m}$ depth layer (simulation using PISCES data; data not showed) and then monthly average satellite images where used for a better simulation.

and at $60-40^{\circ} \mathrm{S}$ with a progressive increase in depth down to about $100 \mathrm{~m}$.

It is however important to note that the model only estimate the season and depth for which the growth is maximal and thus does not consider important processes such as the vertical mixing within the stratified layer, possible sedimentation of animals through the thermocline or enhanced potential predation near the surface which can all results in translocation of the individuals to deeper depth than expected by considering temperature and food that are the only parameters taken into account in this study.

\section{Discussion}

\subsection{General considerations:}

After calibration of the model against laboratory experiments (Fig. 1) and multinet data (Fig. 3), our model has been validated by comparing the modelled data with various independent data sets obtained with plankton tows and core tops sampling (Figs. 4-8) and succeeds to represent generally more than half of the observed variability. Our work suggests that physiological adaptations control to a large degree the species distribution of foraminifers. Our approach is intermediate between trait based models and habitat suitability models. Trait based models are usually concentrated on simulating a whole variety of traits (i.e. physiological abilities) and afterward define a species by analogy between simulated successful combination of traits and existing species or functional groups of organisms presenting these traits (Bruggeman and Kooijman, 2007; Follows et al., 2007; McGill et al., 2006). In contrast, habitat suitability models, also called niche models, use field abundance or presence observations in order to statistically estimate the suitable environmental conditions for each species (Hirzel and Le Lay, 2008). Because habitat suitability models are based on observations that could not represent all possible combinations of environmental conditions (Guisan and Thuiller, 2005) or biotic interactions (Davis et al., 1998), it is recognized that a statistical approach could be inappropriate when extrapolating to novel situations, for example, using scenarios of climatic changes (Davis et al., 1998; Kearney and Porter, 2004). Indeed, it has been argued that only mechanistic process based models (e.g. Kearney and Porter, 2004; Morin et al., 2008) can approach the fundamental niche (Guisan and Thuiller, 2005), and, if based on laboratory or field observations of processes, could facilitate good extrapolation within changing environments (Davis et al., 1998; Kearney and Porter, 2009). We have attempted to fulfil this goal by constructing a model, as much as possible, on laboratory observations of foraminiferal physiology. Thus the FORAMCLIM model is particularly relevant for paleostudies and future climate change studies.

However, with little information on the foraminifer population biology (i.e. fecundity, reproduction, mortality, individual sizes), it was not realistic to develop a mechanistic model of the species abundance. Our model does only simulate abundances using the positive correlation between observed abundance and the model-simulated growth rates (Fig. 3). This correlation was then used to directly convert the growth rates, simulated by the mechanistic part of the model, to abundance. Although introducing an empirical part in our model, this procedure has several advantages: It allows simplifying the model without introducing population 
biology, for which a large part of the processes are neither quantified nor demonstrated. Consequently, this empirical relationship (Fig. 3) combines all population biology in a simple assumption, and allows its calibration with regard to observed abundance.

\subsection{Potential biases of the approach}

The discrepancies observed between observations and model simulations may be explained by many factors including different biases both in the data used to simulate the model, and the data used to validate it, but also potential biases due to the model formulation itself.

\subsubsection{Bias from in situ observations}

The environmental data used to run the model, i.e. hydrological data originating both from satellite sensors or global ecological model, could lead to biases in the comparison between model results and in situ foraminifer distribution. Only in the case of multinet data used for calibration, all hydrological data $\left(T^{\circ} \mathrm{C}\right.$, Chl- $a$, Light $)$ have been measured simultaneously with foraminifer sampling. For the foraminifer data base used to validate the model (Bé and Tolderlund, 1971; core tops), the corresponding hydrological data are not available, and we could not take into account the effect of interannual variability, favourable conditions in subsurface waters compared to surface waters when using satellite data and climate changes since the observation. For the plankton net data originating from Bé and Tolderlund (1971), the season of the sampling is not known and sea surface conditions, observed by satellite images where not yet available. Core tops samples (MARGO data base) integrate several decades to centuries of sedimentation and hydrology might have changed between present times and the mean age of core tops samples.

The existence of cryptic species (Kucera and Darling, 2002), of similar morphotypes and possibly different physiology, could impact the data-model comparison. Most of the morphospecies cover several genetically defined species (Darling et al., 2006; Darling and Wade, 2008; Kucera and Darling, 2002) which could have different physiological adaptations. Those have not been checked in the laboratory studies on which the model is constructed and thus were not taken into account. In addition, due to the different sources of data used to both calibrate and validate the model, taxonomic consistency may also be subject to caution. This is particularly relevant concerning intergrade forms between $N$. incompta and $N$. dutertrei. In the case of model-data discrepancies affecting $N$. incompta and $N$. dutertrei, it is important to note that in the MARGO database, $N$. incompta data (also called $N$. pachyderma dextralis) includes $N$. pachyderma (dex) sensus stricto but also the so called "P/D intergrade" which regroups specimens with intermediate forms between $N$. pachyderma (dex) and $N$. dutertrei. This choice has been made globally over the world ocean but may differ from choices made in other studies, notably multinet samplings used for model calibration. This would explain the underestimation of $N$. incompta and overestimation of $N$. dutertrei by our model (for example in the northern Atlantic Ocean). Therefore, in future studies, the methods of combining the P/D intergrade with $N$. dutertrei or $N$. incompta, or keeping this taxonomical class separated should be compared.

Selective sedimentation and dissolution during sedimentation through the water column (Schiebel et al., 2007) of the different species could affect the comparison of model results with the core tops MARGO database. Some species have shells more prone to dissolution (Berger, 1970) notably when $\mathrm{CO}_{3}^{-2}$ concentration is low, such as in the deeper part of Indian and Pacific oceans. For instance, N. dutertrei is known as dissolution resistant and, this may explain why the model does not succeed to reproduce the high proportion of this species observed in core tops from the east equatorial Pacific Ocean (Fig. 6).

The assemblage data, expressed in relative abundance, are subject to error propagation both in core top data and model results: a deviation from observations on one species has an influence on the relative abundance of the other species. This is particularly true in oligotrophic zones where a small deviation in the absolute abundance of one species may have a large impact on the relative abundances of all other species because of the generally low abundance of each species.

\subsubsection{Possible biases from model construction}

Several hypotheses on which the FORAMCLIM model is built may affect its efficiency. The model only considers eight foraminifer species among the most abundant ones both in the water column and in sediment core sampling. Considering more species would certainly change the model results. However, due to the lack of knowledge on their physiology, all foraminifer species could not be considered yet. The model only considers three environmental forcing factors $\left(T^{\circ} \mathrm{C}\right.$, food concentration, and light availability) whereas other parameters can act on foraminifer abundance such as the salinity (Bijma et al., 1990, Siccha et al., 2009), the depth of the mixed layer (Žarić et al., 2005) or the phase in the lunar cycle (Erez et al., 1991; Schiebel et al., 1997).

Our model, like numerous other habitat suitability models, is a static model implying an assemblage is in pseudoequilibrium with its environment (Guisan and Theurillat, 2000). Accordingly, the model cannot reproduce events controlled by population biology and hydrology, such as the effect of delayed response to a bloom (e.g. Fig. 2) and the effect of transport of assemblages by oceanic currents. Only bottom-up processes are considered meaning that predation and competition are not taken into account. An empirical relationship has been used to relate the simulated growth rates to estimated abundances (Fig. 3). Whereas a 
good correlation exists between these growth rate and abundance, the variability is high and could potentially lead to large biases when comparing model estimations with discrete observations such as plankton tows or sediment trap data. This means that the model only allows to represent a mean ideal foraminifer community, and to calculate a potential abundance.

Despite all these possible biases, the model seems to reproduce efficiently the general pattern of foraminifer species dominance as well as the relative abundance of species, and the total abundance of specimens.

\subsubsection{Comparison with previous foraminifer models}

Previous existing models are based on abundance observations and statistical relationships, and are constrained by hypothesis on unknown population dynamic parameters (predation, competition, reproduction success) (Fraile et al., 2008; Žarić et al., 2006). In contrast, the FORAMCLIM model calibration is mostly based on parameters derived from physiological laboratory observations, with a model complexity limited to demonstrated processes. For the few comparable results (see below), the FORAMCLIM model reproduces the species relative abundance with higher confidence than previous modelling studies (Fraile et al., 2008; Žarić et al., 2006). For comparison between the FORAMCLIM model outputs, forced by satellite images or the PISCES model, and core tops, all RMSE are between 5 to $23 \%$ (Table 3), a lower deviation than the $22-25 \%$ obtained by Fraile et al. (2008). N. pachyderma ( $\sin$.) is the only species for which our RMSE (12-19\%) is larger than that of Fraile et al. (2008) (9\%). When compared to the total foraminifer mean abundance from plankton net sampling (Bé and Tolderlund, 1971) (Fig. 5), FORAMCLIM correctly reproduces the observed abundances, with maximum abundance in tropical and equatorial regions, whereas previous modelling studies simulate maximum abundance in temperate zones (Žarić et al., 2006). However, this could be due to the fact that our model simulations and plankton net data correspond to individuals living in surface waters: the abundances of temperate-polar species such as Turborotalita quinqueloba, Globorotalia inflata and Globigerinita glutinata are not simulated, whereas the Žarić et al. (2006) model includes those species and simulates fluxes over the whole surface mixed layer in order to reproduce sediment trap observations. It is therefore possible that, whereas having higher abundance in equatorial zones (Bé and Tolderlund, 1971), maximum flux of shells may be encountered in temperate regions (Žarić et al., 2006).

Whereas previous models estimate the foraminifer assemblages on a 2-D framework reproducing only the mean mixed layer, our model offers the opportunity to estimate foraminifer assemblages over different water depth, when coupled with appropriate data sets of forcing variables (in situ observations or PISCES model). Since some species are known to occur specifically in sub-surface conditions close or below the deep Chl- $a$ maximum (e.g. Schiebel et al., 2001, Kuroyanagi and Kawahata, 2004), this can improve the utility of predictions made by the FORAMCLIM model. For instance, previous attempts to estimate the month of maximum production or the temperature recorded by foraminifers (Fraile et al., 2009a, b) were only considering the euphotic zone as an unique layer, thus ignoring depth localisation of foraminifer species, whereas FORAMCLIM model consider it (Fig. 10), and thus may improve these results.

\subsection{Ecological meaning of parameters}

Several model parameters are related to the affinities of foraminifer species for their environment. For example, $k_{\mathrm{n}}$ values identified from the calibration allow to describe the affinity for food of different foraminifer species: G. ruber is better adapted to oligotrophic conditions $\left(k_{\mathrm{n}}=0.51 \mu \mathrm{gCl}^{-1}\right)$, O. universa, G. sacculifer, G. siphonifera and $N$. dutertrei are more adapted to intermediate conditions between oligotrophic to mesotrophic waters $\left(k_{\mathrm{n}}\right.$ between 1 to $1.75 \mu \mathrm{gCl}^{-1}$ ), whereas $N$. incompta, $N$. pachyderma, and especially $G$. bulloides need abundant food condition to growth $\left(k_{\mathrm{n}}\right.$ about $3.33,4.7$, and $6.84 \mu \mathrm{g} \mathrm{C} 1^{-1}$, respectively). In fact, G. ruber is commonly described as an oligotrophic species (Bé and Tolderlund, 1971; Hemleben et al., 1989). G. bulloides, N. pachyderma, and N. incompta are more common in temperate to polar productive waters (Bé and Tolderlund, 1971), and seem to react positively to strong bloom events (Schiebel et al., 1995). $N$. dutertrei is commonly described as occurring in tropicalsubtropical upwelling or productive areas (Bé and Tolderlund, 1971) but has a similar $k_{\mathrm{n}}$ to $O$. universa, G. sacculifer and $G$. siphonifera that are not considered to be related to enhanced production. This difference should originate in the fact that the three latter species bear symbionts that could help to survive and grow in oligotrophic regions whereas we assumed that $N$. dutertrei is symbiont-barren and, despite a similar $k_{\mathrm{n}}$, may need more food to grow with a similar rate. The assumption that $N$. dutertrei is symbiont-barren whereas it has been described as a facultative symbiontbearing species (Hemleben et al., 1989) may also explains some model discrepancies when compared to core top data. Such a shift in behaviour was difficult to implement in our model. If the "symbiont-barren" hypothesis succeeded to reproduce $N$. dutertrei distribution pattern in Atlantic Ocean, it seems that on the contrary, it does not reproduce correctly the high abundance in southern Indian and equatorial Pacific oceans. If bearing symbionts, $N$. dutertrei would display behaviour intermediate between the current one and $G$. sacculifer (data not shown), which would better agree to observation in Indian and Pacific oceans, but will not agree with observations in the Atlantic Ocean. This may indicate that in Southern Indian and equatorial Pacific oceans conditions $N$. 

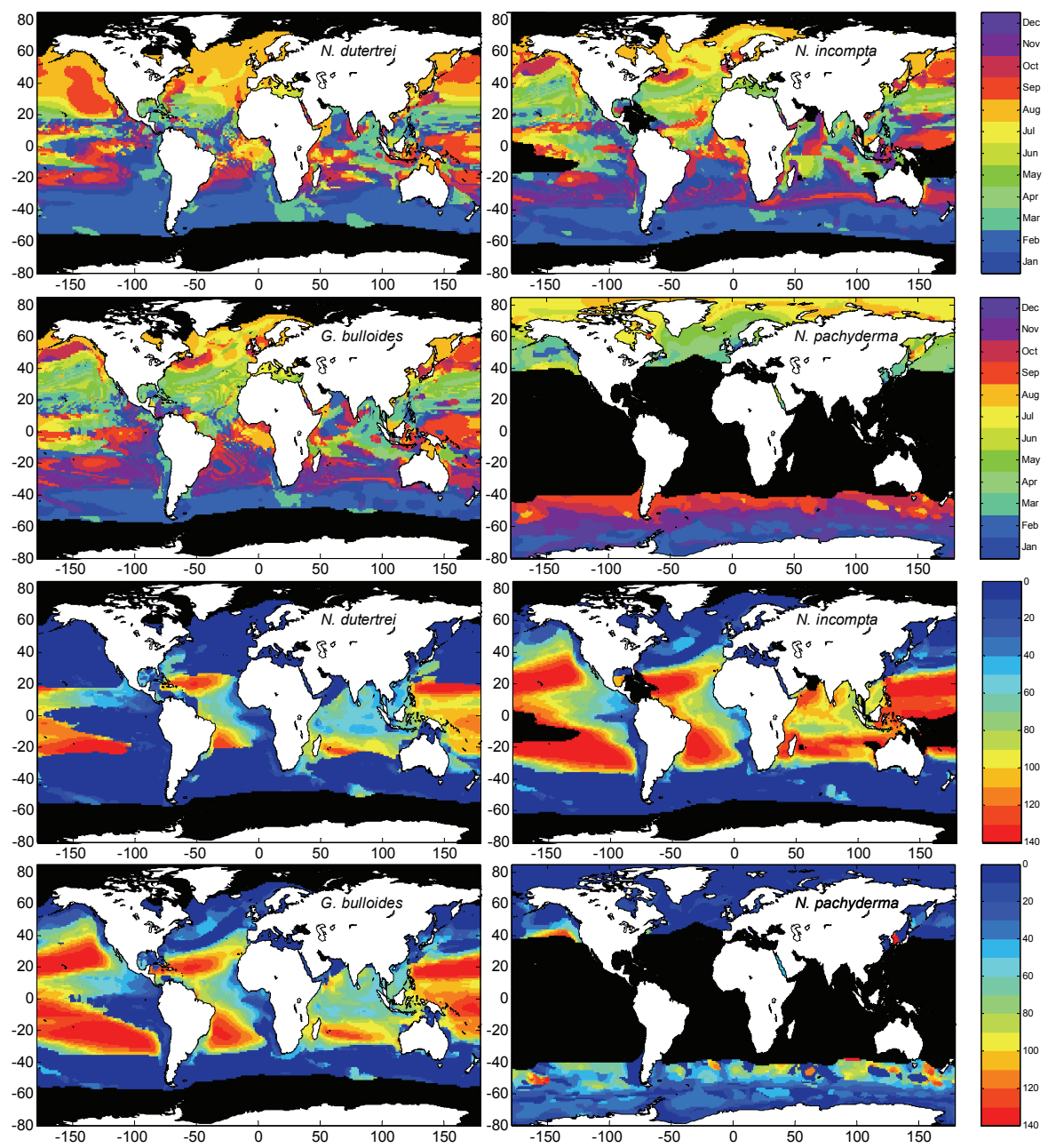

Fig. 10. Estimated season (upper part) and depth location (lower part) of maximum growth rate for N. dutertrei, G. bulloides, N. incompta and $N$. pachyderma. These estimations originate from a simulation using PISCES data.

dutertrei may more frequently use symbionts and then potentially explains the model discrepancies when compared to data.

The $\%_{p}$ parameter gives information on the proportion of material originating from symbiont photosynthesis which is effectively used for growth of the foraminifer-symbiont complex. The $\%_{p}$ parameter has been freely calibrated in order to reproduce foraminifer growth observed in laboratory experiment (Fig. 1). For all the symbiotic considered species, this proportion is comprised between 0.3 and 0.46 indicating that more than $50 \%$ of the photosynthesis is not used for growth of the foraminifer-symbiont complex. Then the model seems to confirm the hypothesis that photosynthesis produces carbon in excess (Jørgensen et al., 1985), and that only a small fraction effectively serves to growth (Lombard et al., 2009a).

\subsection{Current utility and future potential of the model}

Due to the fact that our study links foraminifer physiology, growth potential and potential abundance in natural environments, the FORAMCLIM model has different possible applications. First of all, the growth part of the model gives good simulations of the growth rate of different species for given environmental conditions (Fig. 1). This would support future laboratory experiments, and may provide references to estimate the effect of additional environmental parameters when compared to experimental observations. Moreover, the growth model, once integrated in a population dynamics model, and used in combination with temporal surveys such as sediment traps, may also serve in future studies to estimate reproduction and mortality rates. This will potentially allow using the growth model in a more dynamic way, and without using empirical links between growth rate and abundance (Fig. 3). The entire model also provides a good 
estimation of the distribution of dominant species and relative abundance of the foraminifer assemblage (Figs. 4-8). Therefore, the model can be used as a tool to give a first-order estimate of the distribution of foraminifer species at a given location and to plan samplings of selected species (Figs. 9 and 10). This can notably offer possibility to target selected locations for sampling, where model and data does not agree, and thus where processes not included in the model (e.g. effect of salinity, presence of cryptic species) may mainly control the foraminifer species assemblage. For instance, two populations may correspond to cryptic species in our study: the abundant $G$. bulloides population observed in the Arabian upwelling, and the possibly symbiont-bearing $N$. dutertrei in southern Indian and equatorial Pacific oceans, that the model does not succeed to reproduce. A direct potential application of this model is also to give an indication on the potential season and depth where each species may exhibit their maximal growth rate and then maximal abundance (Figs. 9 and 10). This indication can be useful for numerous paleoclimatic reconstructions in which depth and season are usually assumed. Our model provides a first-order estimate that may strengthen future climatic reconstructions

Another potential application of this model could be to provide a new way to validate global ocean models. A recognized way to validate models is to simulate them under significantly different climatic regimes, such as during the last glacial maximum (LGM) (Le Quéré et al., 2005). However, available data to validate the LGM simulations cover only a small spatial range, and are often hardly comparable (Bopp et al., 2003), whereas large datasets are available on foraminifer composition during LGM (Waelbroeck et al., 2009).

Finally, if the calcification (Lombard et al., 2010) and dissolution processes that takes place during sedimentation (Schiebel et al., 2007) could be integrated in our model, the latter associated with global-scale models may provide first-order estimates of foraminifer impact on calcite fluxes in present, past (LGM) and future conditions in the context of the current global warming.

Acknowledgements. We greatly thank the members of the Forclim Team, Michal Kucera and Ralf Schiebel for constructive discussions and their improvements of the manuscript, the French program ANR05-BLAN0275-01 "FORCLIM" and ANR-10PDOC-005-01 "Ecogely", CEA and CNRS for their support to LSCE, and the Marie Curie Intra-European Fellowship No. 221696.

Edited by: H. Kitazato

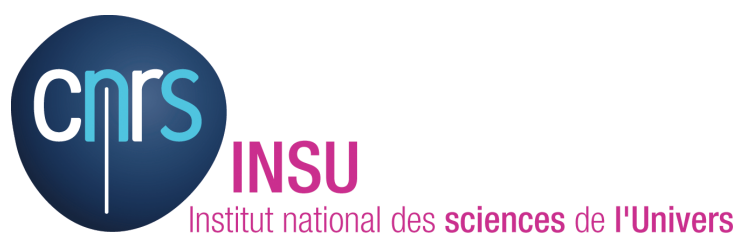

The publication of this article is financed by CNRS-INSU.

\section{References}

Albaina, A. and Irigoien, X.: Fine scale zooplankton distribution in the bay of Biscay in spring 2004, J. Plankton Res., 29, 851-870, 2007.

Aumont, O. and Bopp, L.: Globalizing results from ocean in situ iron fertilization studies, Global Biogeochem. Cy., 20, GB2017, doi:10.1029/2005GB002591, 2006.

Aumont, O., Maier-Reimer, E., Blain, S., and Monfray, P.: An ecosystem model of the global ocean including $\mathrm{Fe}$, Si, P colimitations, Global Biogeochem. Cy., 17, 1060, doi:1010.1029/2001GB001745, 2003.

Barrows, T. T. and Juggins, S.: Compilation of planktic foraminifera modern data from the indo-pacific ocean, PANGAEA database, doi:10.1594/PANGAEA.227317, 2005.

Bé, A. W. H. and Tolderlund, D. S.: 6. Distribution and ecology of living planktonic foraminifera in surface waters of the Atlantic and Indian oceans, in: Micropaleontology of oceans, edited by: Funnell, B. M. and Riedel, W. R., Cambridge University Press, London, UK, 105-149, 1971.

Bé, A. W. H., Caron, D. A., and Anderson, O. R.: Effect of feeding frequency on life processes of the planktonic foraminifer Globigerinoides sacculifer in laboratory cultures, J. Mar. Biol. Assoc. UK, 61, 257-277, 1981.

Berger, W.: Planktonic foraminifera: Selective solution and the lysocline, Mar. Geol., 8, 111-138, 1970.

Bijma, J., Faber, W. W. J., and Hemeleben, C.: Temperature and salinity limits for growth and survival of some planktonic foraminifers in laboratory cultures, J. Foraminiferal. Res., 20, 95-116, 1990

Bopp, L., Kohfeld, K. E., Le Quéré, C., and Aumont, O.: Dust impact on marine biota and atmospheric $\mathrm{CO}_{2}$ during glacial periods, Paleoceanography, 18, 1046, doi:1010.1029/2002PA00810, 2003.

Bruggeman, J. and Kooijman, S.: A biodiversity-inspired approach to aquatic ecosystem modeling, Limnol. Oceanogr., 52, 15331544, 2007.

Cleroux, C., Cortijo, E., Duplessy, J.-C., and Zahn, R.: Deep dwelling foraminifera as thermocline temperature recorder, Geochem. Geophy. Geosy., 8, Q04N11, doi:10.1029/2006GC001474, 2007.

Darling, K. F. and Wade, C. A.: The genetic diversity of planktic foraminifera and the global distribution of ribosomal RNA genotypes, Mar. Micropaleontol.., 67, 216-238, 2008.

Darling, K. F., Kucera, M., Kroon, D., and Wade, C. M.: A resolution for the coiling direction paradox in Neogloboquadrina pachyderma, Paleoceanography, 21, PA2011, doi:10.1029/2005PA001189, 2006.

Davis, A. J., Jenkinson, L. S., Lawton, J. H., Shorrocks, B., and Wood, S.: Making mistakes when predicting shifts in species range in response to global warming, Nature, 391, 783-786, 1998.

Erez, J., Almogi-Labin, A., and Avraham, S.: On the life history of planktonic foraminifera: Lunar reproduction cycle in Globigerinoides sacculifer (Brady), Paleoceanography, 6, 295-306, 1991.

Faber, W. W. J., Anderson, O. R., Lindsey, J. L., and Caron, D. A.: Algal-foraminiferal symbiosis in the planktonic foraminifer Globigerinella aequilateralis: I. Occurence and stability of two mutually exclusive chrysophyte endosymbionts and their ultrastructure, J. Foraminiferal Res., 18, 334-343, 1988. 
Field, D. B.: Variability in vertical distributions of planktonic foraminifera in the california current: Relationships to vertical ocean structure, Paleoceanography, 19, PA2014, doi:10.1029/2003PA000970, 2004.

Follows, M. J., Dutkiewicz, S., Grant, S., and Chisholm, S. W.: Emergent biogeography of microbial communities in a model ocean, Science, 315, 1843-1846, 2007.

Forsythe, W. C., Rykiel, E. J., Stahl, R. S., Wu, H. I., and Schoolfield, R. M.: A model comparison for daylength as a function of latitude and day of year, Ecol. Modell, 80, 87-95, 1995.

Fraile, I., Schulz, M., Mulitza, S., and Kucera, M.: Predicting the global distribution of planktonic foraminifera using a dynamic ecosystem model, Biogeosciences, 5, 891-911, 2008, http://www.biogeosciences.net/5/891/2008/.

Fraile, I., Mulitza, S., and Schulz, M.: Modeling planktonic foraminiferal seasonality: Implications for sea-surface temperature reconstructions, Mar. Micropal., 72, 1-9, 2009a.

Fraile, I., Schulz, M., Mulitza, S., Merkel, U., Prange, M., and Paul, A.: Modeling the seasonal distribution of planktonic foraminifera during the Last Glacial Maximum, Paleoceanography 24, PA2216, doi:10.1029/2008PA001686, 2009 b.

Gallegos, C. L. and Moore, K. A.: Factors contributing to water column light attenuation, in: Chesapeake bay submerged aquatic vegetation water quality and habitat-based restoration targets: A second technical synthesis, US Environmental protection agency, chesapeake bay program, 35-54, 2000.

Gasol, J. M., del Giorgio, P. A., and Duarte, C. M.: Biomass distribution in marine planktonic communities, Limnol. Oceanogr., 42, 1353-1363, 1997.

Gastrich, M. D. and Bartha, R.: Primary productivity in the planktonic foraminifer Globigerinoides ruber (d'Orbigny), J. Foraminiferal. Res., 18, 137-142, 1988.

Geider, R. J., MacIntyre, H. L., and Kana, T. M.: Dynamic model of phytoplankton growth and acclimation: Responses of the balanced growth rate and the chlorophyll a:carbon ratio to light, nutrient-limitation and temperature, Mar Ecol. Prog. Ser., 148, 187-200, 1997

Guisan, A. and Theurillat, J. P.: Equilibrium modeling of alpine plant distribution: How far can we go?, Phytocoenologia, 30, 353-384, 2000.

Guisan, A. and Thuiller, W.: Predicting species distribution: Offering more than simple habitat models, Ecol. Lett., 8, 993-1009, 2005.

Hayes, A., Kucera, M., Kallel, N., Sbaffi, L., and Rohling, E.: Compilation of planktic foraminifera modern data from the Mediterranean sea, PANGAEA database, doi:10.1594/PANGAEA.227305, 2005.

Hemleben, C., Spindler, M., and Anderson, O. R.: Modern planktonic foraminifera, Springer-Verlag, New York, USA, 363 pp., 1989.

Hirzel, A. H. and Le Lay, G.: Habitat suitability modelling and niche theory, J. Appl. Ecol., 45, 1372-1381, 2008.

Imbrie, J. and Kipp, N. G.: A new micropaleontological method for quantitative paleoclimatology: Application to a late pleistocene cribbean core, in: The late cenozoic glacial ages, edited by: Turekian, K. K., Yale Univ. Press, New Haven. Conn., 71$181,1971$.

Jørgensen, B. B., Erez, J., Revsbech, N. P., and Cohen, Y.: Symbiotic photosynthesis in a planktonic foraminiferan, Globigeri- noides sacculifer (Brady), studied with microelectrods, Limnol. Oceanogr., 30, 1253-1267, 1985.

Kearney, M. and Porter, W. P.: Mapping the fundamental niche: Physiology, climate, and the distribution of a nocturnal lizard, Ecology, 85, 3119-3131, 2004.

Kearney, M. and Porter, W.: Mechanistic niche modelling: Combining physiological and spatial data to predict species' ranges, Ecol. Lett., 12, 334-350, 2009.

King, A. L. and Howard, W. R.: Delta O-18 seasonality of planktonic foraminifera from southern ocean sediment traps: Latitudinal gradients and implications for paleoclimate reconstructions, Mar. Micropaleontol., 56, 1-24, 2005.

Köhler-Rink, S. and Kühl , M.: The chemical microenvironment of the symbiotic planktonic foraminifer Orbulina universa, Mar. Biol. Res., 1, 68-78, 2005.

Kucera, M. and Darling, K. F.: Cryptic species of planktonic foraminifera: Their effect on palaeoceanographic reconstructions, Philos. T. R. Soc. A, 360, 695-718, 2002.

Kucera, M., Weinelt, M., Kiefer, T., Pflaumann, U., Hayes, A., Weinelt, M., Chen, M.-T., Mix, A. C., Barrows, T, T., Cortijo, E., Duprat, J., Juggins, S., and Waelbroeck, C.: Compilation of planktic foraminifera census data, modern from the Atlantic Ocean, PANGAEA database, doi:10.1594/PANGAEA.227322, 2005.

Kucera, M., Rosell-Melé, A., Schneider, R., Waelbroeck, C., and Weinelt, M.: Multiproxy approach for the reconstruction of the glacial ocean surface (MARGO), Quat. Sci. Rev., 24, 813-819, 2005.

Kuroyanagi, A. and Kawahata, H.: Vertical distribution of living planktonic foraminifera in the seas around Japan, Mar. Micropaleontol., 53, 173-196, 2004.

Le Quéré, C., Harrison, S. P., Prentice, I. C., Buitenhuis, E. T., Aumont, O., Bopp, L., Claustre, H., Da Cunha, L. C., Geider, R., Giraud, X., Klaas, C., Kohfeld, K. E., Legendre, L., Manizza, M., Platt, T., Rivkin, R. B., Sathyendranath, S., Uitz, J., Watson, A. J., and Wolf-Gladrow, D.: Ecosystem dynamics based on plankton functional types for global ocean biogeochemistry models, Glob. Change Biol., 11, 2016-2040, 2005.

Lombard, F., Erez, J., Michel, E., and Labeyrie, L.: Temperature effect on respiration and photosynthesis of the symbiont-bearing planktonic foraminifera Globigerinoides ruber, Orbulina universa, and Globigerinella siphonifera, Limnol. Oceanogr., 54, 210-218, 2009a.

Lombard, F., Labeyrie, L., Michel, E., Spero, H. J., and Lea, D. W.: Modelling the temperature dependent growth rates of planktic foraminifera, Mar. Micropaleontol., 70, 1-7, $2009 \mathrm{~b}$.

Lombard, F., da Rocha, R. E., Bijma, J., and Gattuso, J.-P.: Effect of carbonate ion concentration and irradiance on calcification in planktonic foraminifera, Biogeosciences, 7, 247-255, 2010, http://www.biogeosciences.net/7/247/2010/.

Lorenzen, C. J.: Extinction of light in ocean by phytoplankton, J. Cons. Int. Explor. Mer, 34, 262-167, 1972.

McGill, B. J., Enquist, B. J., Weiher, E., and Westoby, M.: Rebuilding community ecology from functional traits, Trends Ecol. Evol., 21, 178-185, 2006.

Michaels, A. F., Caron, D. A., Swanberg, N. R., Howse, F. A., and Michaels, C. M.: Planktonic sarcodines (acantharia, radiolaria, foraminifera) in surface waters near Bermuda: Abundance, biomass and vertical flux., J. Plankton Res., 17, 131-163, 1995. 
Morin, X., Viner, D., and Chuine, I.: Tree species range shifts at a continental scale: New predictive insights from a process-based model, J. Ecol., 96, 784-794, 2008.

Rink, S., Kühl, M., Bijma, J., and Spero, H. J.: Microsensor studies of photosynthesis and respiration in the symbiotic foraminifer Orbulina universa, Mar Biol., 131, 583-595, 1998.

Schiebel, R.: Planktic foraminiferal sedimentation and the marine calcite budget, Global Biogeochem. Cy., 16, 1065, doi:1010.1029/2001GB001459, 2002.

Schiebel, R. and Hemleben, C.: Interannual variability of planktic foraminiferal populations and test flux in the eastern North Atlantic Ocean (JGOFS), Deep Sea Res. II, 47, 1809-1852, 2000.

Schiebel, R., Hiller, B., and Hemleben, C.: Impacts of storms on recent planktic foraminiferal test production and $\mathrm{CaCO}_{3}$ flux in the north Atlantic at $47^{\circ} \mathrm{N}, 20^{\circ} \mathrm{W}$ (JGOFS), Mar. Micropaleontol., 26, 115-129, 1995.

Schiebel, R., Bijma, J., and Hemleben, C.: Population dynamics of the planktic foraminifer Globigerina bulloides from the eastern north Atlantic, Deep-Sea Res., 44, 1701-1713, 1997.

Schiebel, R., Waniek, J., Bork, M., and Hemeleben, C.: Planktic foraminiferal production simulated by chlorophyll redistribution and entrainment of nutrients, Deep-Sea Res. Pt. I, 48, 721-740, 2001.

Schiebel, R., Zeltner, A., Treppke, U. F., Waniek, J. J., Bollmann, J., Rixen, T., and Hemleben, C.: Distribution of diatoms, coccolithophores and planktic foraminifers along atrophic gradient during SW monsoon in the Arabian sea, Mar. Micropaleontol., 51, 345-371, 2004.

Schiebel, R., Barker, S., Lendt, R., Thomas, H., and Bollmann, J.: Planktic foraminiferal dissolution in the twilight zone, Deep-Sea Res. Pt. II, 54, 676-686, 2007.

Siccha, M., Trommer, G., Schulz, H., Hemleben, C., and Kucera, M.: Factors controlling the distribution of planktonic foraminifera in the Red Sea and implications for paleoenvironmental reconstructions by transfer functions, Mar. Micropaleontol., 72, 146-156, 2009.

Spero, H. J. and Parker, S. L.: Photosynthesis in the symbiotic planktonic foraminifer Orbulina universa and its potential contribution to oceanic productivity, J. Foraminiferal Res., 15, 273$281,1985$.
Takahashi, K. and Bé, A. W. H.: Planktonic-foraminifera - factors controlling sinking speeds, Deep-Sea Res., 31, 1477-1500, 1984.

Takahashi, T., Broecker, W. S., and Bainbridge, A. E.: Supplement to the alkalinity and total carbon dioxide concentration in the world oceans, in: Carbon cycle modelling, scope, edited by: Bolin, B., J. Wiley and Sons, Chichester, UK, 159-199, 1981.

Taylor, A. H., Geider, R. J., and Gilbert, F. J. H.: Seasonal and latitudinal dependencies of phytoplankton carbon-to-chlorophyll a ratios: Results of a modelling study, Mar. Ecol. Prog. Ser., 152, 51-66, 1997.

Waelbroeck, C., Paul, A., Kucera, M., Rosell-Melee, A., Weinelt, M., Schneider, R., Mix, A. C., Abelmann, A., Armand, L., Bard, E., Barker, S., Barrows, T. T., Benway, H., Cacho, I., Chen, M. T., Cortijo, E., Crosta, X., de Vernal, A., Dokken, T., Duprat, J., Elderfield, H., Eynaud, F., Gersonde, R., Hayes, A., Henry, M., Hillaire-Marcel, C., Huang, C. C., Jansen, E., Juggins, S., Kallel, N., Kiefer, T., Kienast, M., Labeyrie, L., Leclaire, H., Londeix, L., Mangin, S., Matthiessen, J., Marret, F., Meland, M., Morey, A. E., Mulitza, S., Pflaumann, U., Pisias, N. G., Radi, T., Rochon, A., Rohling, E. J., Sbaffi, L., Schafer-Neth, C., Solignac, S., Spero, H., Tachikawa, K., Turon, J. L., and Members, M. P.: Constraints on the magnitude and patterns of ocean cooling at the last glacial maximum, Nat. Geosci., 2, 127-132, 2009.

Watkins, J. M., Mix, A. C., and Wilson, J.: Living planktic foraminifera: Tracers of circulation and productivity regimes in the central equatorial Pacific, Deep-Sea Res. Pt. II, 43, 1257$1282,1996$.

Watkins, J. M., Mix, A. C., and Wilson, J.: Living planktic foraminifera in the central tropical Pacific ocean: Articulating the equatorial "cold tongue" during la nina, 1992, Mar. Micropaleontol., 33, 157-174, 1998.

Žarić, S., Donner, B., Fischer, G., Mulitza, S., and Wefer, G.: Sensitivity of planktic foraminifera to sea surface temperature and export production as derived from sediment trap data, Mar. Micropaleontol., 55, 75-105, 2005.

Žarić, S., Schulz, M., and Mulitza, S.: Global prediction of planktic foraminiferal fluxes from hydrographic and productivity data, Biogeosciences, 3, 187-207, 2006, http://www.biogeosciences.net/3/187/2006/. 